\title{
The novel technology for reservoir stimulation: in situ generation of carbon dioxide for the residual oil recovery
}

\author{
Geylani M. Panahov ${ }^{1} \cdot$ Eldar M. Abbasov $^{1}$ (1) $\cdot$ Renqi Jiang $^{2}$
}

Received: 11 October 2020 / Accepted: 20 February 2021 / Published online: 23 March 2021

(c) The Author(s) 2021

\begin{abstract}
The gas and chemical flooding for reservoir stimulation with residual hydrocarbons reserves are highly relevant problem of current oil and gas recovery strategy. The objective of this paper is laboratory study and field implementation of new gas-EOR technology—in situ carbon dioxide generation technique for $\mathrm{CO}_{2}$-liquid slug formation under oil displacement, increasing the reservoir sweep efficiency and residual oil recovery. This paper presents a summary of a wide range of laboratory tests conducted on different core samples and chemical compositions. Several physical and hydrodynamic phenomena of in situ $\mathrm{CO}_{2}$ generation in highly permeable zones of a porous medium have been investigated as a part of complex study, which involved laboratory tests on the field-scale industrial technology applications, determination of optimal concentrations of foaming agents and inhibiting additives in gas-releasing solutions, etc. The results of laboratory experiments showed that the incremental recovery ranged between 30 and $35 \%$ oil original in place. The unique results of the field implementation provide developing an optimal technological scheme of reservoir stimulation with residual oil reserves both onshore and offshore oil fields. Technology of in situ $\mathrm{CO}_{2}$ generation was applied on the group of wells on Penglai offshore oil field (Bohai Bay). Incremental oil production for field operation was $37,740 \mathrm{bbl}$ of crude oil. Theoretical and laboratory studies, as well as the outcomes of industrial implementation of a new method of residual oil recovery, using a $\mathrm{CO}_{2}$-slug confirm technology and economic profitability of the proposed solution.
\end{abstract}

Keywords Carbon dioxide $\cdot$ Gas flooding $\cdot$ In situ generation $\cdot$ Oil displacement $\cdot$ Sweep efficiency $\cdot$ Gas-liquid slug

\section{Introduction}

The downward trend in oil production at a significant number of mature oil and gas fields is one of the main reasons for enhanced oil recovery technologies becoming an important and definitive factor in the recovery of residual oil reserves (Farajzadeh et al. 2021, Mofrad and Dehaghani 2020).

In oil-producing regions, the main volume of hydrocarbons is recovered with water flooding technology in combination with tertiary methods of enhanced (EOR) and improved oil recovery (IOR) (Fig. 1) (Sondak 2018, Lake et al. 2014). Carbon dioxide injection as a tertiary method during the water flooding stage is one of the ways to increase

Eldar M. Abbasov

eldar.abbasov@imm.az

1 Institute of Mathematics and Mechanics, Azerbaijan National Academy of Sciences, Baku, Azerbaijan

2 GCC Group Corp, Beijing, China oil recovery, extend the life of field and increase the profitability of the field in general (Dake 1998, Liu et al. 1975, Hussain et al. 2020). Due to the fact of the potential benefits, there is an industrial interest in the $\mathrm{CO}_{2}$-EOR-based methods. The wide implementation of such projects is hindered mainly by the lack and remoteness of industrial $\mathrm{CO}_{2}$ sources with regard to the oil fields and weak financial and economic outputs that address environmental problems (Kristanto et al. 2020, Hu et al. 2020, Al Yousef et al. 2020, Shakhverdiev and Panahov 2000). A relatively effective way to recycle carbon dioxide is to use it in the EOR processes. Despite the existence of an extensive pipeline infrastructure for $\mathrm{CO}_{2}$ transportation in the main oil producing regions, the risks associated with the capture and storage of $\mathrm{CO}_{2}$ during transport and storage operations (the necessity of a detailed study of the physical and chemical processes in the reservoirs; the optimal placement, that accounts for the seismic activity of the gas storage area; captured $\mathrm{CO}_{2}$ phase evaluation, etc.) significantly reduce the possibility of $\mathrm{CO}_{2}$ utilization in 


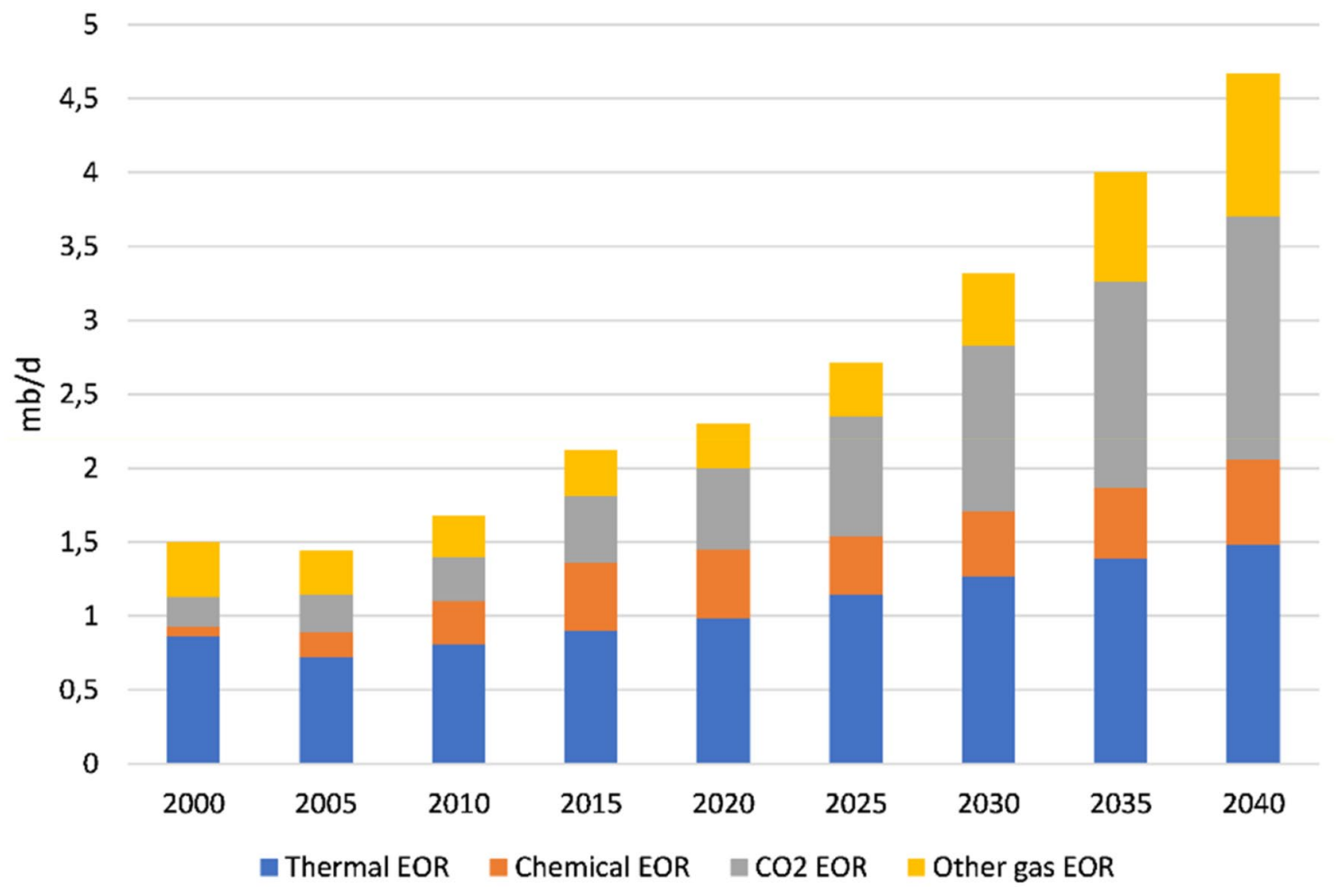

Fig. 1 Actual and forecast distribution of methods for increasing oil recovery under the new energy policy (New Policies Scenario)

EOR processes (Assef and Almao 2019, Yousef et al. 2020, Choubineh et al. 2019, Eide et al. 2019).

The effectiveness and demand for carbon dioxide technologies are confirmed by more than 35 years of global experience in implementing $\mathrm{CO}_{2}$ injection processes for enhanced oil recovery. In the USA, there are more than 13,000 wells involved in $\mathrm{CO}_{2}$-EOR projects, more than $5600 \mathrm{~km}$ of highpressure pipelines have been constructed for $\mathrm{CO}_{2}$ transportation, and more than 600 million tons of carbon dioxide has been injected into the reservoirs and about 245,000 bpd of oil produced under $\mathrm{CO}_{2}$-EOR projects (Valluri et al. 2020; Eide et al. 2019; Zhang et al. 2016). Field operations of carbon dioxide injection are widely applied on the oil fields in China, with large-scale projects performed during injection of flue gases with a high content of carbon dioxide (as thermal power plants waste) (Hu et al. 2020; Kim and Lee 2017; Zhang et al. 2016).

A number of carbon dioxide flooding projects are being implemented over Liaohe oil field, the third largest oil field in China, which is currently experiencing a decline in oil production ( $\mathrm{Hu}$ et al. 2020). The field test of $\mathrm{CO}_{2}$ EOR technology is carried out on the power plant Huafu Electrical Appliance Co., Ltd., the flue gases of which are injected into the reservoir, because of high carbon dioxide content of $12-13 \%$. It is well known that the implementation of EOR projects is largely determined by the influence of the economic situation and oil prices. The initiation of
EOR technologies depends on the willingness of investors to manage the potential financial risks of such innovations, the possible economic effect, as well as the availability of attractive investment opportunities (Farzaneh et al. 2016).

An effective solution of these limitations was found in the area of rheo-gas-chemical technologies for in situ generation of carbon dioxide (Bakhtiyarov 2006; Huang and Holm 1988; Hussain et al. 2020; Panakhov and Omrani 2008; Speight 2019). Carbon dioxide is an active "energy" component of the gas-liquid slug formation reaction, which have the properties of directed (oriented) action on stagnant and poorly drained reservoir zones. Carbon dioxide gas, generated as a result of gas-liquid slug formation, and its other critical characteristics make its utilization in the recovery of hard-to-recovery oil (Saleh and Mukaila 2019, Panakhov and Omrani 2008; Zhang et al. 2004; Rodosta 2017).

In situ generation of carbon dioxide is more effective in terms of changing the thermobaric conditions of the reservoir, and naturally affects the dynamics of the filtration process, changing viscosity ratio of the chemical solutions involved in the rheochemical reaction, the volume factor, residual oil saturation, etc. $\mathrm{CO}_{2}$ dissolution in the reservoir fluids leads to the changes in their rheophysical characteristics. The main technological advantage of the new in situ techniques of $\mathrm{CO}_{2}$ generation is the ability to control the volume and pressure of the formed gas (gas-liquid) slug while 
minimizing capital and operating expenditures for planning the field operations and following application.

In situ generation of desired volumes of carbon dioxide eliminates several drawbacks of conventional technologies of production, such as a delivery and injection of $\mathrm{CO}_{2}$ gas. By retaining the advantages of gas stimulation of the reservoir, new in situ techniques generate the localized highpressure zones in the reservoir, which stimulate the recovery of residual oil from stagnant zones of the formation. Although it is possible to generate significant amounts of carbon dioxide, by controlling the injection of the reacting chemical solutions, technology avoids generation of the extra gas saturation in reservoir conditions and following carbon dioxide breakthrough in producing wells, which is observed during implementation of the conventional technologies (Choubineh et al. 2019). In this case, it is possible to expand the process over time, providing periodic "energy recharge" of hard-to-reach areas of the reservoir as a whole, with effective oil displacement by water-gas slug.

\section{Methodology}

\section{Aims and assumptions}

The purpose of the laboratory experiments was to evaluate the efficiency of the new technique under the field implementation and the choice of technological parameters. In the experiments, a selection of chemical agents used as additives to gas-releasing and gas-forming water solutions in field operations was made.

Experimental setup was designed and built in order to test the volume and the pressure of the generated $\mathrm{CO}_{2}$ gas from the new technique. Effect of the process components on the miscibility of the $\mathrm{CO}_{2}$ gas was investigated. Gas generation properties of the gas-releasing and gas-forming compositions involved in new technology were measured. Experiments were conducted to measure the volume and the pressure of the $\mathrm{CO}_{2}$ gas generated according to the new method. An experimental apparatus was designed, built and used for these purposes. The designed setup allowed initiating and controlling the reaction between the "gas-releasing" and "gas-forming" agents. An aqueous solution of acid with the special chemical additives was used as a gas-releasing solution, and a neutral salt of carbonic acid was used as a gasforming solution. The temperature was controlled and the gas composition was analyzed during the reaction process.

A sweep efficiency enhancement using foams, polymers and surfactant formulations proposed by new technology was studied experimentally. This core work will be directed at evaluating the steady-state mobility properties of the foams in individual cores, each with a different permeability so that a wide range of permeability is covered Fig. 2.

\section{$\mathrm{CO}_{2}$ generation kinetics study}

In order to analyze the features of $\mathrm{CO}_{2}$ generation process, the laboratory tests were performed on the carbon dioxide generation in a PVT cell and in the core samples (porous medium). Results of the first series of experiments in the PVT cell show the effect of physical and chemical characteristics on the generated gas volume and pressure dynamics during that reaction of gas-releasing and gas-forming solutions (Figs. 3 and 4). The water phase of chemical agents used in laboratory tests was distilled fresh water and reservoir water of Binagady oil field (Azerbaijan), with the physical and chemical characteristics given in Tables 1 and 2.

The results of the stoichiometric reaction between gas-releasing aqueous solutions formed on the basis of distilled, fresh and reservoir water have proven that the pressure and volumetric characteristics of the reaction differ depending on the type of water phase involved in the reaction. This difference is reflected, primarily, in the rate of pressure change during the carbon dioxide release at the initial stage of the reaction (Fig. 3).

Considering, it is natural that solubility of generated carbon dioxide in formation water is significantly less than solubility in fresh water, used as the aqueous phase of the gas-releasing agent. The rate of pressure buildup differs significantly for separate types of water-based gas-releasing chemical compositions. The rate of pressure buildup during the reaction of $10 \mathrm{ml}$ of chemical solutions was $d P /$ $d t=180 \mathrm{~Pa} / \mathrm{min}$ for distilled water, $d P / d t=212 \mathrm{~Pa} / \mathrm{min}$ for fresh water; and $d P / d t=638 \mathrm{~Pa} / \mathrm{min}$ during experiments with reservoir water. The results obtained are important for saturation front line control during gas flooding (Frenkel 1975; Jia et al.2019).

At the next stage of laboratory tests, gas-releasing reaction in core samples (composed of $95 \%$ quartz sand and $5 \%$ montmorillonite clay) was evaluated. Here we find a slightly different effect from the previous tests-the increase in the pressure at the beginning of test to some extreme value, and then slight drop in the values. Porous medium effects on the dynamics of pressure changes during the stoichiometric reaction-relationship between pressure and gas release is non-equilibrium (Fig. 4, curves $1,2)$. In contrast, $\mathrm{CO}_{2}$ generation in porous medium from gas-releasing solution prepared from the formation water, displays the monotonous pressure dynamics (Fig. 4, curve 3).

Thermodynamic conditions of $\mathrm{CO}_{2}$ solubility define dependence of this parameter on the pressure and temperature-as the pressure increases, the solubility of carbon dioxide increases, while during the constant pressure, the change is controlled by the temperature (Figs. 5 and 6). 
Fig. 2 Flowchart of laboratory and field study of in situ $\mathrm{CO}_{2}$ generation

Fig. 3 Pressure buildup curve of $\mathrm{CO}_{2}$ generation in different water types chemical solution (stoichiometric reaction in PVT cell)
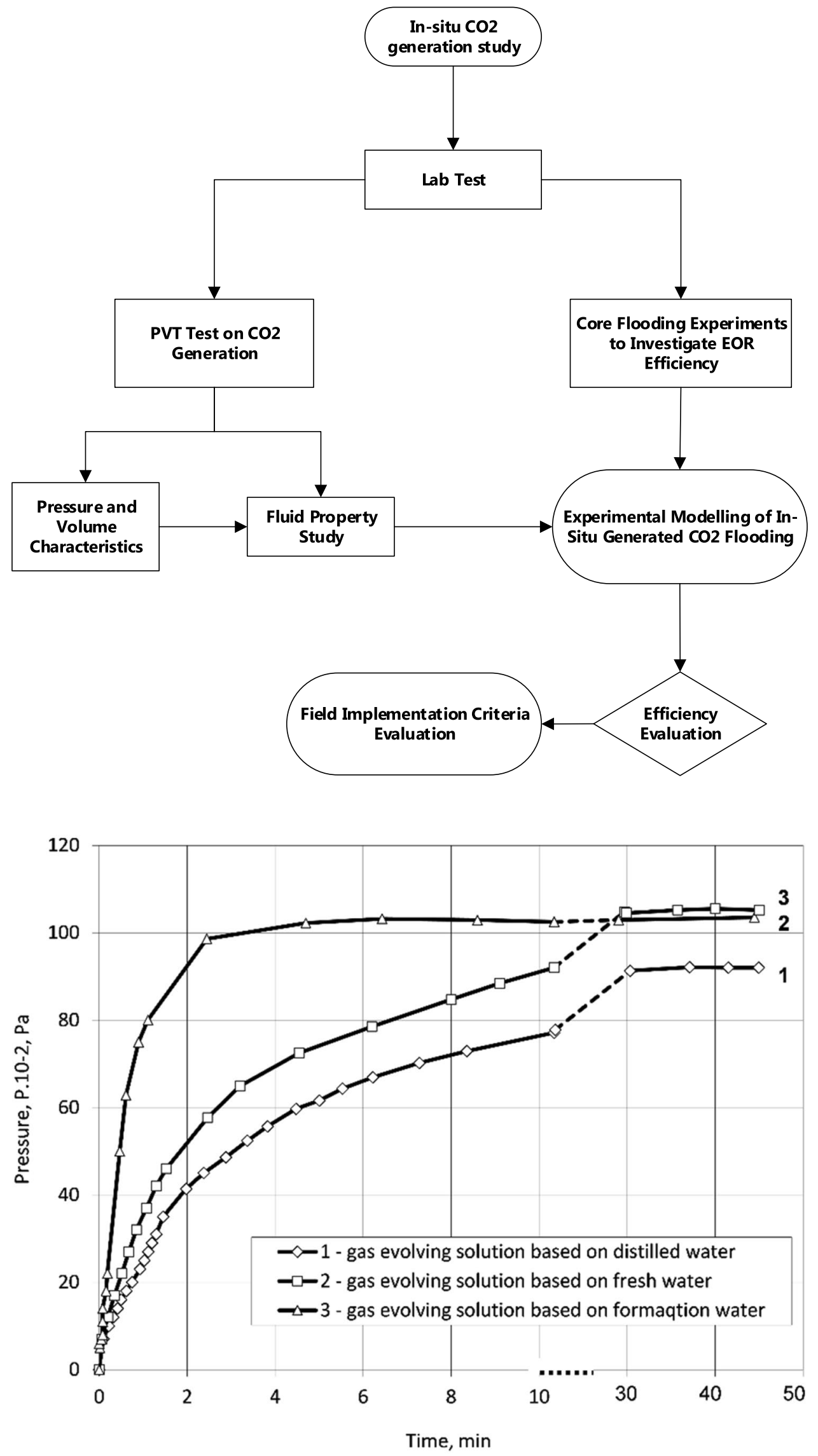
Fig. 4 Pressure buildup curve during the reaction of gasreleasing and gas-forming solutions (different water types) in a porous medium $(95 \%$ quartz sand and 5\% montmorillonite clay)

Table 1 Physical and chemical properties of fresh water sample (Shollar water type, Azerbaijan)

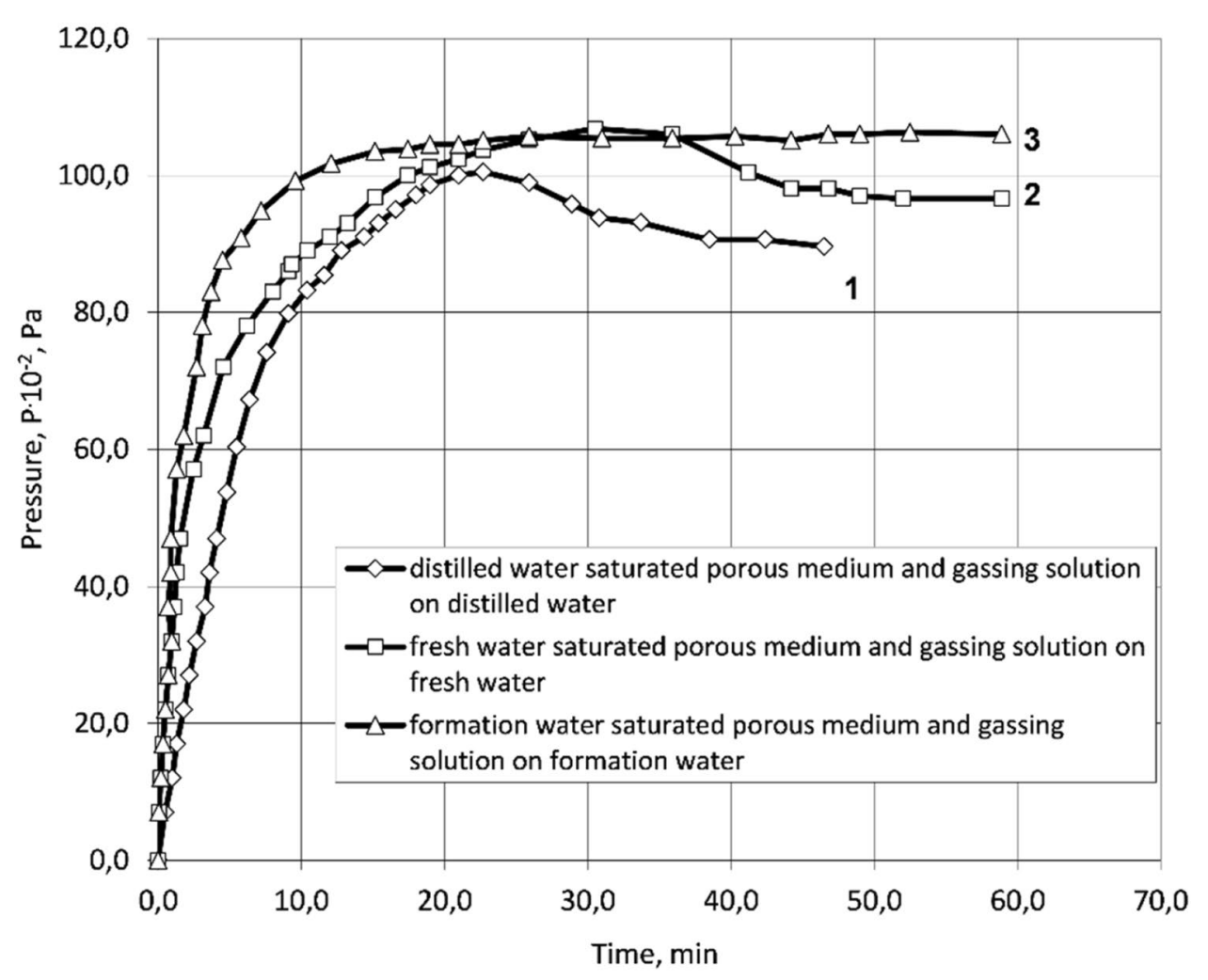

\begin{tabular}{lllllllll}
\hline $\mathrm{Ca}^{2+}$ & $\mathrm{Mg}^{2+}$ & $\mathrm{Ca}^{2+}+\mathrm{Mg}^{2+}$ & $\mathrm{Na}^{+}$ & $\mathrm{Cl}^{-}$ & $\mathrm{SO}_{4}{ }^{2-}$ & $\mathrm{HCO}_{3}{ }^{-}$ & $\Sigma K$ & $\mathrm{SiO}_{3}{ }^{2-}$ \\
\hline $\mathrm{mEq} / \mathrm{l}$ & & & 0.5 & 0.2 & 1.9 & 4.4 & 6.5 & 18.2 \\
3.8 & 2.2 & 6.0 & 0.2 \\
\hline
\end{tabular}

\begin{tabular}{llllllll}
\hline $\mathrm{Ca}^{2+}$ & $\mathrm{Mg}^{2+}$ & $\mathrm{Na}+\mathrm{K}$ & $\mathrm{Cl}$ & $\mathrm{SO}_{4}{ }^{2-}$ & $\mathrm{HCO}_{3}+\mathrm{CO}_{3}$ & $\mathrm{RCOO}$ & $\mathrm{HB}_{4} \mathrm{O}_{7}$ \\
\hline $\mathrm{mEq} / \mathrm{l}$ & & & & & & & \\
15.0 & 24.6 & 17.9 & 771.8 & 4.2 & 27.9 & 9.1 & 1.4 \\
\hline
\end{tabular}

Table 2 Physical and chemical properties of formation water sample of Binagady oil field (Azerbaijan)

\section{Theoretical background}

For mathematical characterization of the gas-releasing relationships, we can use exponential functions for relaxation model in the form of linear first-order differential equations. However, this approach will not capture all details of gas generation processes, especially for high mineralization fluids. Assuming, that the previously released gas bubbles ( $C$-concentration of bubbles) partially dissolve, and also contribute to slowing down of gas release, we assume that the rate of bubbles generation is as follows:

$v=v_{1}-v_{2} C-v_{3} C^{2}$

where $v_{1}$-the rate of gas formation without interference; $v_{2}$-rate of dissolution of gas bubbles; $v_{3}$ - the rate of slowing down the formation of new gas bubbles; $C$ - gas bubbles concentration.

The nonlinear models in the form of kinetic equations, describing gas releasing, are also proposed in the manner similar to the one mentioned below:

$\frac{\mathrm{d} C}{\mathrm{~d} t}=v-\alpha C$

where $\alpha$-solubility factor.

$\frac{\mathrm{d} C}{\mathrm{~d} t}=v_{1}-v_{2} C-v_{3} C^{2}-\alpha C$

Assuming that there is a linear relationship between bubble concentration and pressure: 
Fig. 5 Calculated volumes of generated carbon dioxide under different thermodynamic parameters of stoichiometric chemical reaction

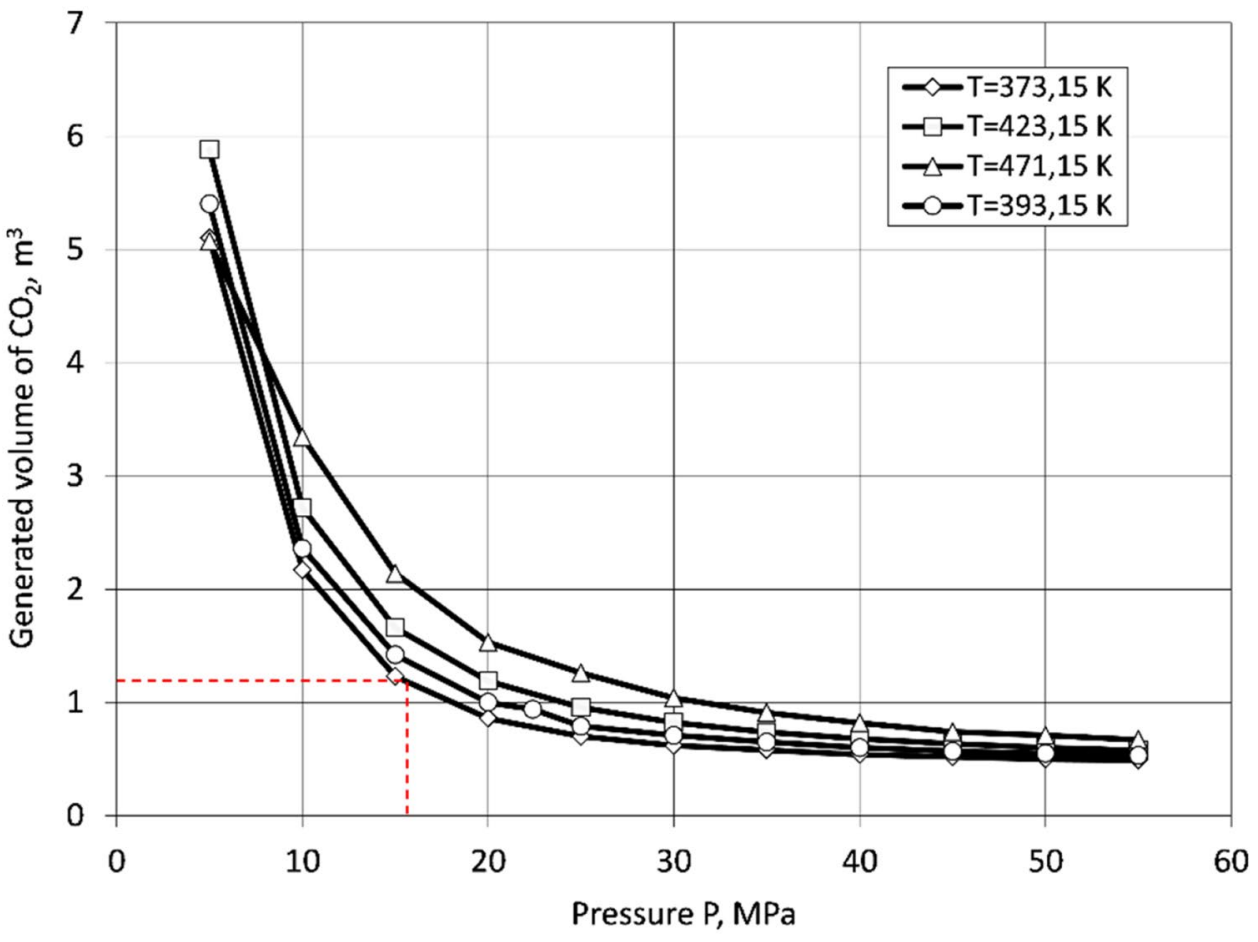

Fig. 6 Estimated volume of generated carbon dioxide under various thermodynamic conditions of stoichiometric chemical reaction of acid solution and neutral salt of carbonic acid

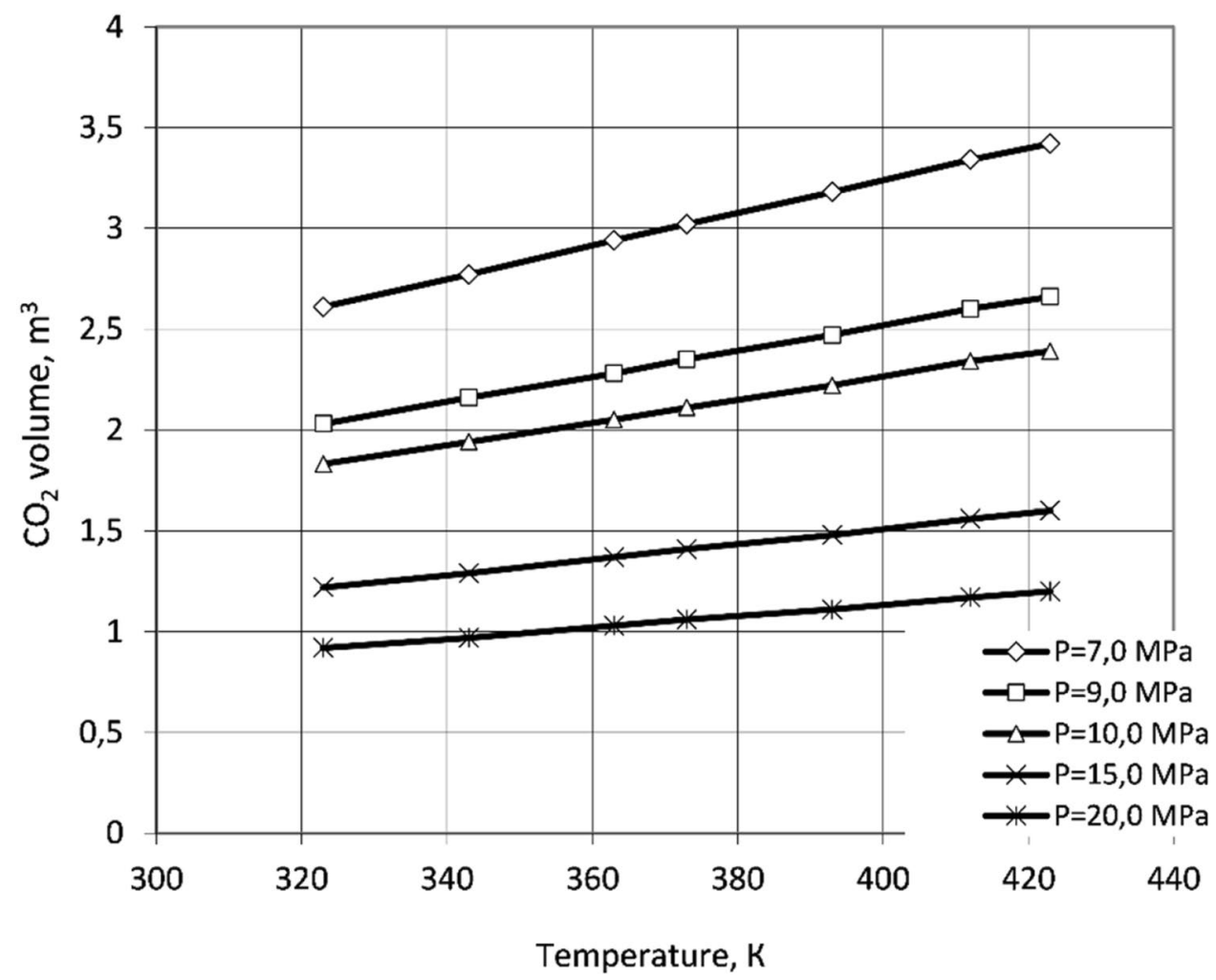

$\frac{\mathrm{d} P}{\mathrm{~d} t}=k v_{1}-\left(\alpha+v_{2}\right) P-\frac{v_{3}}{k} P^{2}$

$P=k C$.

Assume that

$k$-rate of pressure change.

Then, the kinetic equation will be: 
$a_{1}=k_{1} v_{1}$-parameter that affects the change in pressure under gas release;

$a_{2}=\alpha+v_{2}$-parameter that takes into account the effect of partial dissolution of gas nuclei on the pressure change;

$a_{3}=\frac{v_{3}}{k}$ - a coefficient that accounts for the influence of already existing gas nuclei on the pressure change.

Then, we get:

$\frac{\mathrm{d} P}{\mathrm{~d} t}=a_{1}-a_{2} P-a_{3} P^{2}$

To estimate the coefficients $a_{1}, a_{2}, a_{3}$, the method based on the theory of sensitivity was used. If there are coefficients $\left(a_{2}\right.$ and $\left.a_{3}\right)$ that correspond to the partial dissolution of the bubbles and the influence of already formed gas nuclei, respectively, on pressure change, the solution (4) will have the form:

$P=\frac{1}{2 a_{3}}\left[A\left(1-\frac{2}{1+e^{A(t+c)}}\right)-a_{2}\right]$

where $A=\sqrt{a_{2}^{2}+4 a_{1} a_{3}}$ - (Fig. 3-curves 1 and 3).

As it follows from the experiments, in the case of the reservoir water used as the water phase of the gas-releasing solution (such as Binagady oil field), the coefficient that controls the effect of dissolution of the gas nuclei, is negligible. Therefore, Eq. (4) can be written as:

$\frac{\mathrm{d} p}{\mathrm{~d} t}=a_{1}-a_{3} P^{2}$

which can be presented as a dependency of pressure $P$ vs. time $t$.

$P=\sqrt{\frac{a_{1}}{a_{3}}\left(1-\frac{2}{1+e^{2 \sqrt{a_{1} a_{3}}(t+C)}}\right)}$

describing curve 2 (Fig. 3).

The pressure drop at the final stage of gas release in porous medium is caused by the adsorption of gas bubbles on the surface of the pore channels, followed by diffusion of gas molecules into the rock grains (Al-Saedi et al. 2019; Kristanto et al. 2020; Bila and Torsæter 2020; Mukaila and Saleh 2020). In this case, the expression describing the formation and dissolution of gas bubbles is possible in the form(Mandrik et al. 2010):

$\frac{\mathrm{d} P}{\mathrm{~d} t}=a_{1}-a_{2} P(t)-a_{3} P^{2}(t-\tau)$

$a_{2}$ and $a_{3}$-coefficients that determine the pressure change taking into account the influence of gas molecules formed and diffusing into the rock particles, respectively;

- the characteristic time of diffusion.
In general, solution of Eq. (8) is searched up in the form:

$t \geq t_{0}, P(t)=P_{0}(t), t \in E_{t o}=\left(t_{0}-\tau, t_{0}\right]$

In the case when the $\mathrm{CO}_{2}$ gas generation reaction takes place in porous media and aqueous phase gas-evolving solution is formation water, equation can be written as (7), the solution of which can be represented in the form of the dependence of $P$ on $t$ (Eq. (8), describing a curves 1 and 2 (Fig. 4)).

Now, let us find a solution that satisfies these conditions. Assume that $\tau>0$ is a lag constant. On the segment of the function $P_{0}(t)$, the function $a_{1}-a_{2} P(t)-a_{3} P^{2}(t-\tau)$ at $t \geq t_{0}$ is continuous.

First, consider the solution of problem (8-9) on the segment $I_{1}=\left[t_{0}, t_{0}+\tau\right]$. Obviously, when $t_{0} \leq t \leq t_{0}+\tau$. Consequently, for $t \in I_{1}(t-\tau)=P_{0}(t-\tau)$ and the problem is finding a simple differential equation that satisfies the condition

$P\left(t_{0}\right)=P_{0}\left(t_{0}\right)$

Here, the function $F(t)=a_{1}-a_{2} P(t)-a_{3} P_{0}^{2}(t-\tau)$ on the segment $t_{0} \leq t \leq t_{0}+\tau$ is continuous. Then, from Peano theorem, there is a solution of functions (8), (11) on segments $\left[t_{0}, t_{0}+\alpha\right], 0<\alpha \leq \tau$.

Assuming that $\alpha<\tau$, the solution is searched up to $I_{1}$. Denoting this solution as $P_{1}(t)$ and continuing the process

$P(t)=\left\{\begin{array}{c}P_{0}(t), t \in E_{t 0} \\ P_{1}(t), t \in I_{1} \\ P_{2}(t), t \in I_{2}\end{array}\right.$

then the function $P(t)$ is the solution (8-9).

The solution of the problem is presented in the form:

$P(t)= \begin{cases}P_{1}(t)=\sqrt{\frac{a_{1}}{a_{3}}\left(1-\frac{2}{\left.1+e^{2 \sqrt{a_{1} a_{3}}(t+c)}\right)} ;\right.} \quad\left(t_{0}-\tau, t_{0}\right] \\ P_{1}(t)+\frac{C+a_{2}-a_{3} e^{C(t-\tau)}}{-2 a_{3}} ; & t \in I_{1} .\end{cases}$

Actually, the solution of the problem is: $P(t)=e^{2 t-e^{2}(t-\tau)}$.

The conducted experiments draw to a conclusion that during the use of gas-releasing aqueous solutions formed from the reservoir water, there is a rapid rate of gas release into the third phase at the initial moments of the reaction. In addition, the absence of a diffusion factor leads to the best result in the distribution of water and oil saturation in the displacement zone. Intensive gas release at the initial stage of the reaction slows down the speed of the frontal saturation spike, while the rate of reservoir flooding is reduced in 
comparison with fresh water as a consequence. This conclusion is clearly confirmed by the results of laboratory experiments on the oil displacement using $\mathrm{CO}_{2}$ slug prepared from formation water as aqueous phase of the gas-releasing solution. A sequence of simultaneously ongoing irreversible processes in a non-equilibrated system provides integrative efficiency of residual oil displacement.

\section{Coreflood experiments}

Oil displacement from the porous medium by gas-releasing and gas-forming solutions was studied, as the part of the laboratory tests (Panakhov and Abbasov 2004). Laboratory experiments were carried out on the core samples simulating reservoir in the state of conditions, presented in Table 3. The experimental setup is shown in Fig. 7.

The core sample was $14.31 \mathrm{~cm}$ in length, with the diameter of $2.5 \mathrm{~cm}$. Porosity of the sample was $39.68 \%$, while gas and water permeability, respectively, are also shown in
Table. 3. To prevent gas and liquid channeling between the porous medium and test cell, an abrasive layer is created on the wall of the steel core holder by mixing quartz sand with epoxy glue. After the mixture has solidified, then the core sample is placed in the core holder.

The reservoir properties of the Penglai oil field (Bohai Bay) pilot site were previously modeled.

1. Saturation of the core sample with reservoir waterdetermination of the core permeability. All elements of the experimental setup were connected by copper tubes. A constant temperature was maintained in the PVT cell and core holder by means of rubber hoses that circulated water from the thermostat. The PVT cell was filled with a water sample, and water was pumped through the tubes into the core sample. To achieve full saturation of the model with reservoir water, five-six pore volumes were injected through the sample. The pressure sensors were used to measure the pressure at the inlet and outlet of the core sample. The water permeability was determined. The experimental installation

Table 3 Core samples properties

\begin{tabular}{llllll}
\hline Core sample & $\begin{array}{l}\text { Water sample } \\
\text { (well \#) }\end{array}$ & $\begin{array}{l}\text { Core sample } \\
\text { length, cm }\end{array}$ & $\begin{array}{l}\text { Core sample } \\
\text { diameter, cm }\end{array}$ & $\begin{array}{l}\text { Permeability, } \\
\mathrm{mD}\end{array}$ & Pore volume, ml \\
\hline 1 & E1 & 7.2 & 2.51 & 615 & 18.3 \\
2 & E2 & 7.29 & 2.52 & 910 & 18.1 \\
3 & H1 & 7.53 & 2.49 & 980 & 18.9 \\
4 & H2 & 7.21 & 2.51 & 880 & 18.3 \\
\hline
\end{tabular}

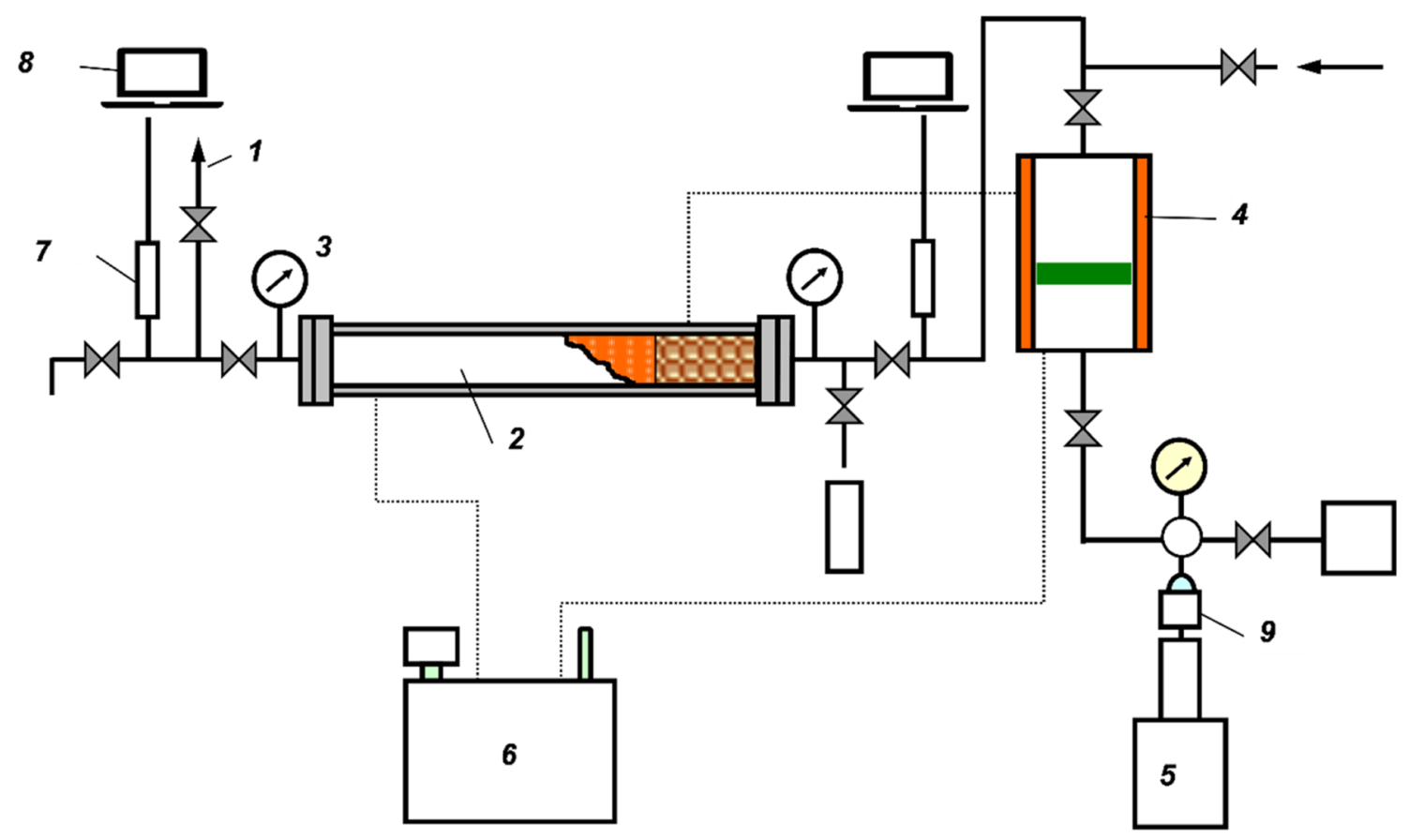

Fig. 7 Experimental setup: 1—vacuum line; 2-porous medium; 3-standard pressure gauge; 4—PVT cell; 5—metric press; 6—ultratermostat; 7-pressure sensor; 8-laptop; 9-pressure control sensor 
was thermostated at a temperature of $65{ }^{\circ} \mathrm{C}$. Flow rate was $0.017 \mathrm{~cm}^{3} / \mathrm{s}$, water viscosity $-\mu_{w}=0.48 \mathrm{mPa} \cdot \mathrm{s}$. The pore volume $V_{p}$ of the core under test was determined.

2. Next, water was displaced by oil to simulate an initial oil saturation with residual water saturation. In the PVT cell, water was replaced with a sample of reservoir oil, and then, oil was injected to the model input. Thus, the initial oil saturation conditions were modeled:

$S_{\text {oil in }}=(15.8 / 18) 100 \%=88 \%$.

3. Oil displacement by injected water-simulated conditions of the flooding of the reservoir. To do this, the PVT cell was filled with a water sample and water was pumped to the model input. Four pore volumes of water were injected. During the third stage of oil displacement by reservoir water, the flow rate was maintained at $Q=0.017 \mathrm{~cm}^{3} / \mathrm{s}$. Four pore volumes of water were injected- $54 \mathrm{ml}$, while the volume of displaced oil was $V_{\text {oil }}=8.6 ; 7.4 ; 7.0$ and $7.0 \mathrm{ml}$ for four different core samples, respectively. The dynamics of pressure change is shown in Fig. 8. Residual oil saturation after third stage was:

$\left.S_{\text {res. }}=(15.8-7.2) / 18\right) 100 \%=(8.6 / 18) 100 \%=47.7 \%$

4. Displacement of residual oil with $\mathrm{CO}_{2}$-slug: gas-releasing and gas-forming aqueous solutions of chemical agents were previously prepared. As a gas-releasing agent, a 9\% aqueous solution of acid (AS) with additives of inhibitors was used, and as a gas-forming solution, a 12\% aqueous solution of the neutral salt of carbonic acid (NSCA) with additives of a water-soluble polymer of the acrylic group and an additional chemical have been used. Sequentially and alternating portions of gas-releasing and gas-forming solutions were injected through four pores volumes of displacement fluid (Table 4).

The parameters of the injection of chemical solutions of gas-generating agents during the consequent oil displacement were as follows: flow rate $-Q=0.017 \mathrm{~cm}^{3} / \mathrm{s}$, while the volume of displaced oil for different cores was $V_{\text {oil }}=6.5$; 6; 6; $6.3 \mathrm{ml}$, respectively. Pressure changes in the porous medium during the injection of gas-generating solutions are characterized by periodic fluctuations and shown in Fig. 8.

Chemical reaction between the chemical reaction occurring between the gas-releasing compositions leads to the release of $\mathrm{CO}_{2}$, the formation of a gas-liquid slug, a local increase in pressure in the channels, and the redirection of the displacing fluid to the stagnant filtration zones.

Residual oil saturation was determined: $S_{\text {res. } \mathrm{CO} 2}=(8,6-6$ ,5) $/ 18) \cdot 100 \%=2,1 / 18=11,6 \%$.

Comparison of the pressure dynamics under oil displacement by reservoir water (Fig. 8) and in situ generated $\mathrm{CO}_{2}$ slug (Fig. 9) clearly confirms the formation of gas release zones in a porous medium with a periodic gas formation in pore channels not covered by water injection (flooding). Pressure in the reaction zone is higher (1200:500; 200:50) than in other reservoir areas. The nature of the process stimulates the fluid flow diversion to the uncovered pore channels, as a result, an increase in sweep efficiency occurs.

The four core samples were under the tests until displacement factor was stabilized $\left(\sim 3 \div 4 V_{v o l}\right)$. From this point, as gas-releasing solutions were injected, pressure increase was observed, while incremental oil was also
Fig. 8 Dynamics of pressure change under the oil displacement by reservoir water-core sample (95\% quartz sand and $5 \%$ montmorillonite clay)

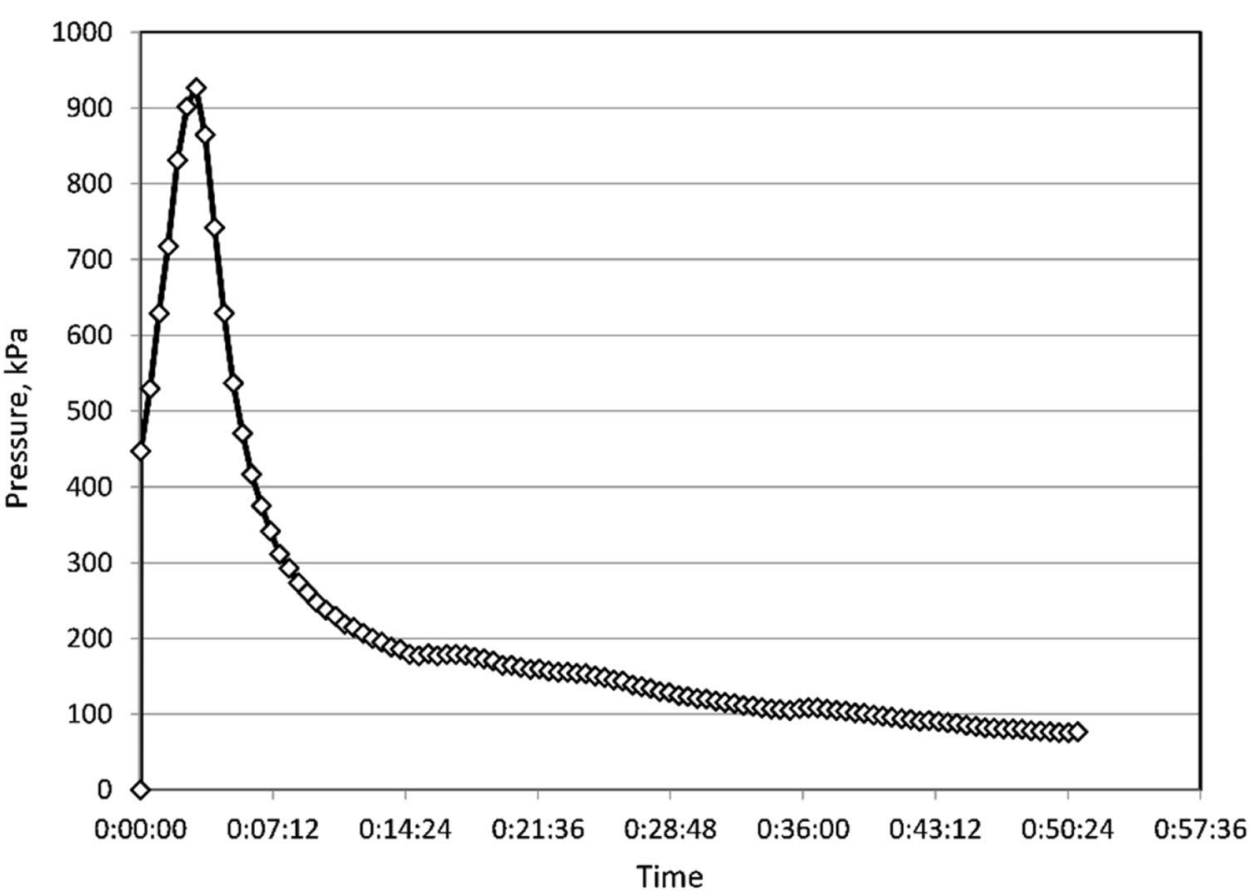

Time 
Table 4 Gas-generating solutions injection algorithm in core samples
Fig. 9 Pressure dynamics under oil displacement by in situ generated $\mathrm{CO}_{2}$ slug

\begin{tabular}{lcclcc}
\hline $\mathrm{CO}_{2}$ generated solutions & Time & Volume, $\mathrm{ml}$ & $\mathrm{CO}_{2}$ generated solutions & Time & Volume, ml \\
\hline Core sample \#1 & & & Core sample \#2 & \\
NSCA & $0: 00$ & 6.0 & NSCA & $0: 00$ & 6.0 \\
AS & $06: 34$ & 6.0 & AS & $07: 04$ & 6.0 \\
NSCA & $12: 37$ & 4.0 & NSCA & $13: 07$ & 4.0 \\
AS & $16: 39$ & 4.0 & AS & $17: 09$ & 4.0 \\
NSCA & $21: 12$ & 4.0 & NSCA & $21: 11$ & 4.0 \\
AS & $24: 43$ & 4.0 & AS & $25: 43$ & 4.0 \\
NSCA & $28: 45$ & 4.0 & NSCA & $29: 15$ & 4.0 \\
AS & $32: 47$ & 4.0 & AS & $33: 17$ & 4.0 \\
Water & $36: 49$ & 18.0 & Water & $38: 49$ & 18.0 \\
Core sample \#3 & & & Core sample \#4 & & \\
NSCA & $0: 00$ & 6.0 & NSCA & $0: 00$ & 6.0 \\
AS & $06: 05$ & 6.0 & AS & $07: 02$ & 6.0 \\
NSCA & $12: 08$ & 4.0 & NSCA & $13: 09$ & 4.0 \\
AS & $16: 10$ & 4.0 & AS & $17: 15$ & 4.0 \\
NSCA & $20: 12$ & 4.0 & NSCA & $21: 12$ & 4.0 \\
AS & $24: 13$ & 4.0 & AS & $25: 13$ & 4.0 \\
NSCA & $28: 15$ & 4.0 & NSCA & $29: 11$ & 4.0 \\
AS & $32: 17$ & 4.0 & AS & $32: 47$ & 4.0 \\
Water & $36: 19$ & 18.0 & Water & $36: 19$ & 18.0 \\
\hline & & & & &
\end{tabular}

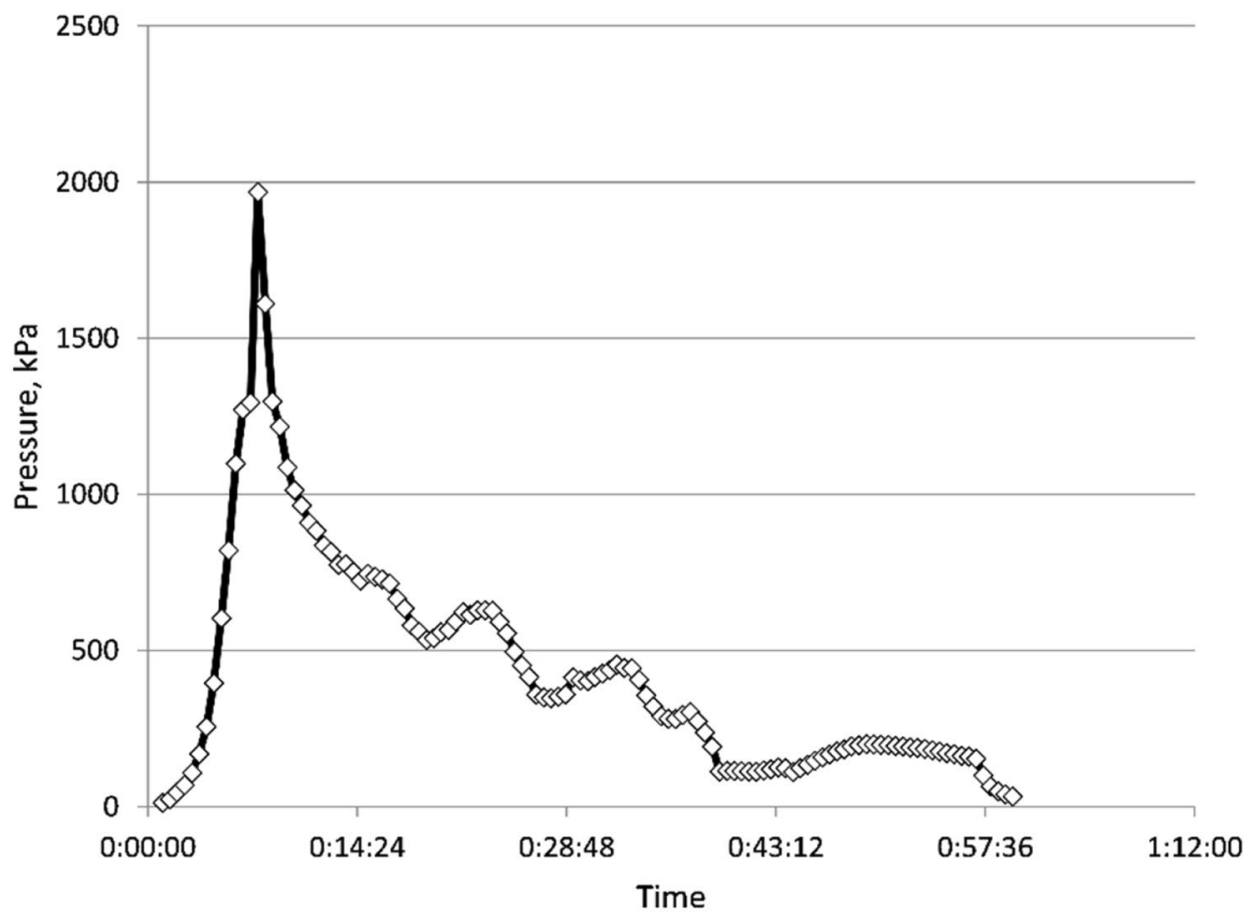

recovered from core sample. The incremental recovery ranged between 30 and $35 \%$ oil original in place. Table 5 shows the results of core flooding experiments.

\section{Results of laboratory test}

Thus, the experiment carried out on 4 samples of artificial cores (quartz sandstone) showed the following: 
Table 5 Laboratory tests on oil displacement by in situ generated $\mathrm{CO}_{2}$ slug

\begin{tabular}{llllll}
\hline Core sample & $\begin{array}{l}\text { Group of } \\
\text { wells }\end{array}$ & $V_{\mathrm{p}}, \mathrm{ml}$ & $V_{\mathrm{o}}, \mathrm{ml}$ & $\begin{array}{l}\text { Residual oil volume } \\
\left(V=3 V_{\mathrm{p}}\right), \mathrm{ml}\end{array}$ & $\begin{array}{l}V_{\text {oil }} \text { (after displace- } \\
\text { ment by } \mathrm{CO}_{2} \text { slug), } \\
\mathrm{ml}\end{array}$ \\
\hline $1^{*}$ & $\mathrm{E}$ & 18.3 & 15.8 & 7.2 & 6.5 \\
$2^{*}$ & $\mathrm{E}$ & 18.1 & 16.4 & 9 & 6.0 \\
$3^{* *}$ & $\mathrm{H}$ & 18.9 & 17 & 10 & 6.0 \\
$4^{* *}$ & $\mathrm{H}$ & 18.3 & 15.5 & 8.5 & 6.3 \\
\hline
\end{tabular}

*H well group samples; **E well group samples
1. The oil displacement factor by water after injection of three pore volumes was achieved until its value stabilized to the level of the current oil displacement factor on oil field.

2. At the stage of oil displacement by the injected water, the value of residual oil saturation was reached, corresponding to the current value of oil saturation in the field.

3. At the contact of the injected portions of the aqueous acid solution and the average carbonic acid salt in the pores of the core sample, an increase in pressure and an increase in oil recovery factor (30-35\% oil in place) have been observed at the core outlet.

Laboratory results established the technology adaptation principles for field-scale application. Newly developed method of in situ carbon dioxide generation and formation of a gas-liquid slug has potentially effective possibilities for obtaining industrially significant results for residual oil recovery. The implementation of the new $\mathrm{CO}_{2}$ technology provides high economic and technological efficiency in accordance with the geological, technical and technological conditions of various fields (Hu et al. 2020; Tian et al. 2014; Mandrik et al. 2010; Shakhverdiev and Panahov 2010).

\section{Field implementation.}

A set of theoretical and laboratory studies provided the foundation for the application of technology across the number of Chinese oil fields-both on- and offshore.

Reservoir rocks across fields in China, in majority, are represented by sandstone or the mixture of sandstone and conglomeratic rocks, consisting mainly of detritus (Mandrik et al. 2010). Most oil fields belong to the fluvio-deltaic depositional systems, the permeability of which varies widely and is characterized by a clearly defined anisotropy (Tian et al. 2014; Trivedi and Babadagli 2009).

The long-term development and exploitation of China's oil and gas reserves eventually led to a gradual decline in the recoverable volumes. Most of the existing oil fields in China are mature oil fields and are currently characterized by low reservoir pressure and oil saturation. This factor leads to the categorization of recoverable reserves to the group of hard-to-recover reserves (Hu et al. 2020).

Since the mid-1970 s, China has widely used the hydrocarbon gases (alkanes) injection technology, which led to the $90 \%$ growth in oil recovery (Hou 2016; Höök 2010; Shakhverdiev 2008). However, due to the high cost and limited supply of such agents, there was a need to identify cheap replacement for the alkanes. Since the $1980 \mathrm{~s}$ of the twentieth century, nitrogen and carbon dioxide have been identified as the substitutes of hydrocarbon gases as an injecting agent. Currently, these newly identified agents have almost completely replaced alkane gases in EOR technology in China. The technological effect proved to be in the interest of the oil production industry, which made it possible to use industrially generated flue gases containing about $10-14 \% \mathrm{CO}_{2} ; \sim 80 \% \mathrm{~N}_{2}$ and a certain amount of excess oxygen as injection agents (Chen et.al 2010).

In the context of innovative solutions for in situ $\mathrm{CO}_{2}$ slug generation, we present the results of industrial application of an innovative EOR technology for residual oil reserves extraction. The next paragraph describes field cases of the in situ gas generation with the formation of a gas-liquid system, which in its turn is used as an oil displacement slug, resulting in improvement of sweep efficiency. Establishing the relationship between thermodynamics conditions of gas saturation to the specific conditions of liquid hydrocarbons occurrence, is an important element of the work (Panakhov et al. 2006; Panakhov and Omrani 2008; Shakhverdiev et al. 2008; Shakhverdiev et al. 2004; Shakhverdiev et al. 2010; Shakhverdiev and Panakhov 2000; Speight 2019).

Technology of in situ $\mathrm{CO}_{2}$ generation was applied on the group of wells on Penglai offshore oil field (Bohai Bay), operated by CNOOC oil company with the support of the COSL Service Company. The well treatment operations were carried out with the cycled injection of gas-forming and gas-releasing chemical compositions on two injection wells.

The well treatment was carried out on two groups of wells: group of injection well \#E25 and seven responding production wells and group of injection well \#H5 and eight responding wells. 
Comparative analysis of proposed groups of the wells on the subject of conformity to the requirements of the pilot treatment has displayed that the permeability and porosity of the reservoir $(19.7-4997 \mathrm{mD}$, porosity-29-29\%), lithology, reservoir flooding performance of production wells correspond to the optimal case of the effective technology realization. Heavy oils are in abundant proportion in reservoir fluids, and in situ viscosity is $57.0-338.0 \mathrm{mPa}$ 's. Oil viscosity at surface conditions is $983.0-4565.0 \mathrm{mPa}$ 's. Reservoir fluids are presented by the highly mineralized, chlorocalcium and sodium types of the fluids, and the mineralization values are within the range of $4481-7154 \mathrm{mg} / \mathrm{l}$.

It should be noted that carbon dioxide generated under injection of gas-generating compositions is a favorable factor affecting the reduction of viscosity, and provides a volumetric effect in the extracted oil and stimulation of additional inflow to the producing wells.

The production wells' performance and water breakthrough events were monitored after the conclusion of the stimulating operations. Analysis of the water injection through the injection well showed that there is a change in the injection pressure from 1.4 to $5.7 \mathrm{MPa}(\Delta P=4.3 \mathrm{MPa})$, which indirectly points to the increase in hydraulic resistance at the waterfront and flow reorientation in the direction of low-permeable pathways of the formation, previously not covered by displacement procedures.

Injection well treatment operation included sequential injection of aqueous solutions of reacting compositions of chemical agents into the intervals of interest. Chemical compositions were prepared directly at the wellhead.

Trends of oil production and water cut indicators of responding wells showed that there is a positive reaction to the in situ $\mathrm{CO}_{2}$-slug impact, which was expressed as a change in the average daily oil rate and a drop in the water content of the responding wells.

Preliminary results of the technological operation confirmed that the incremental oil production after treatment (taking into account the decrease in production for three production wells) was $37,740 \mathrm{bbl}$ of crude oil.

The average daily flow rate and water cut performance for eight responding production wells, which were subject for the in situ $\mathrm{CO}_{2}$ treatment, are shown in Figs. 10 and 11. It should also be mentioned that these wells are the part of nine-point field production system.

Technology has also been applied on two injection wells on the Penglai offshore field (Bohai Bay). The Penglai 9-1 (PL9-1) oil field, which contains China's third largest offshore oil accumulation, was found in shallow reservoirs $(700-1700 \mathrm{~m})$ within the most active fault zone in east

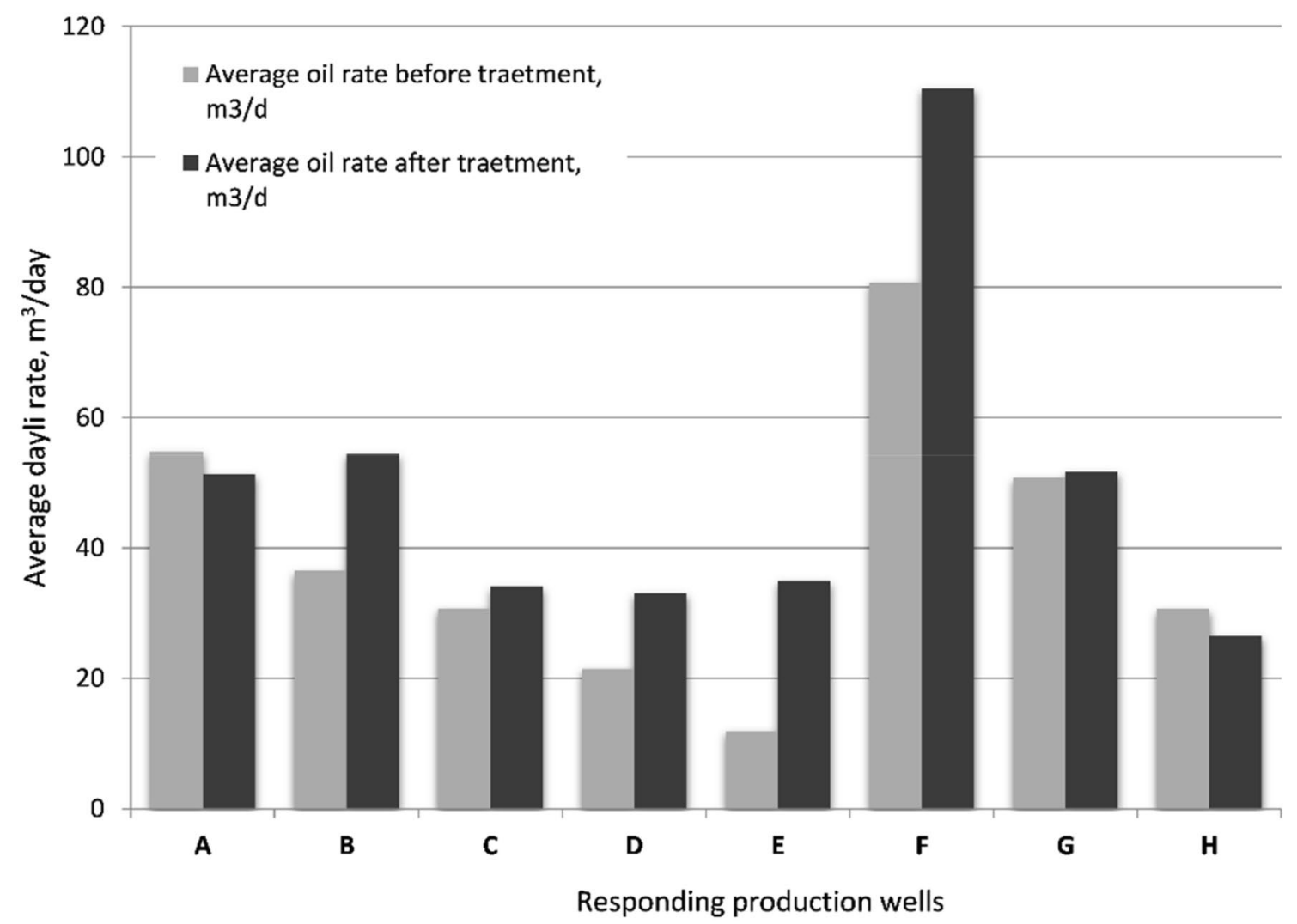

Fig. 10 Trend of the average daily production for eight responding wells at the pilot site of in situ CO2 generation technology implementation 


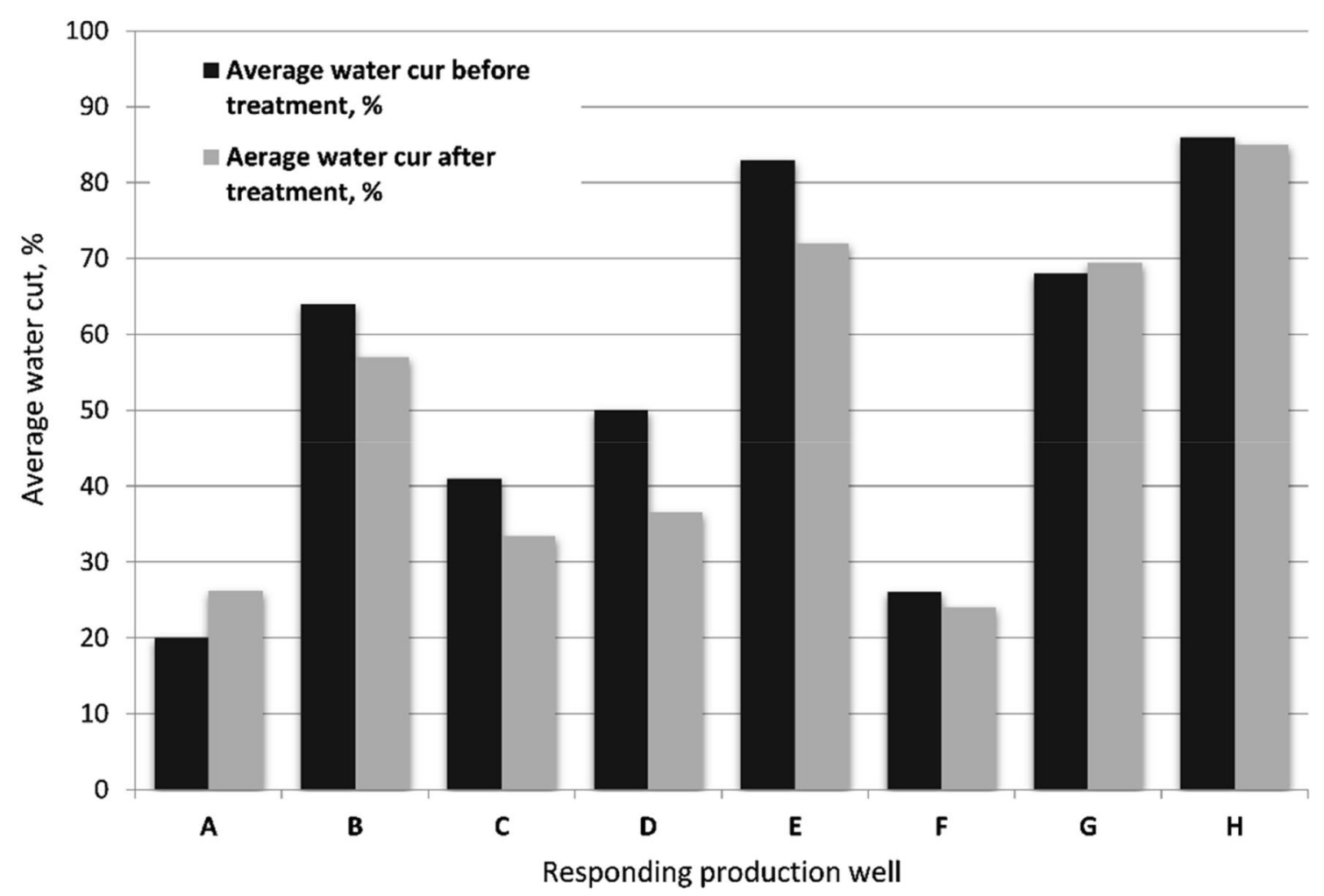

Fig. 11 Trend of water cut of eight responding wells at the pilot site of in situ $\mathrm{CO}_{2}$ generation technology implementation

China. The PL9-1 field contains two oil-bearing series, the granite intrusions in Mesozoic $(\mathrm{Mz})$ and both the sandstone reservoirs in Neogene Guantao $(\mathrm{Ng})$ and Neogene Minghuazhen (Nm) Formation. The Mesozoic granite intrusions, which hold more than $80 \%$ of the oil reserves in the field, were charged in the west by oil generated from the third member (Es3) of the Shahejie Formation in the Bodong depression. The Neogene reservoirs of the PL9-1 field were charged in the west by oil generated from the third member (Es3) of the Shahejie Formation in the Bodong depression and in the south by oil generated from the first member (Es1) of the Shahejie Formation in the Miaoxibei depression. Interactive contact between the large fan delta and the mature source rocks residing in the Es3 Formation of the Bodong depression resulted in a high expulsion efficiency from the source rocks and rapid oil accumulation in the PL9-1 field, which probably explains how can this large oil field accumulate and preserve within the largest and most active fault zone in east China. (Tian et al. 2014).

The PL19-3 formation has good reservoir characteristics and is characterized by moderately high porosity and high permeability (Tables 6,7 ). It should be noted that clay minerals are composed mainly of kaolinite, illite, smectite and chlorite.

The designed volumes of generated gas-liquid slug are based on technological parameters under technology
Table 6 Reservoir characteristics

\begin{tabular}{llllll}
\hline Formation & \multicolumn{2}{l}{ Porosity $(\%)$} & & \multicolumn{2}{l}{ Permeability $(\mathrm{mD})$} \\
\cline { 2 - 3 } \cline { 6 - 7 } \cline { 6 - 7 } & Range & Average & & Range & Average \\
\hline Nm_Lower & $23.5-34.7$ & 30.6 & & $17-2200$ & 606 \\
Ng_Upper & $20.6-32.6$ & 28.3 & & $15-2330$ & 761 \\
Ng_Lower & $18.9-30.0$ & 23.3 & & $18-5900$ & 859 \\
\hline
\end{tabular}

application and excluded of necessity of significant volumes injection under CO2-liquid slug waterflooding. Results of laboratory and field researches confirm that injection of relatively small slug allows reaching satisfying sweep efficiency of $0.5-1.0 \%$ of pore volume.

Estimation of slug volumes is made proceeding from mining method, the scheme of wells arrangement and reservoir characteristics.

Reservoir research covers the following operations: well interference testing; oilfield geometry sizes; formation thickness, oil-saturated interlayer thickness; permeability, porosity; formation pressure, formation temperature; bed intake; injectivity profile, etc.

Main influence factors for successive in situ $\mathrm{CO}_{2}$ generation are: residual reserves; formation pressure, temperature; fluid property (formation water and oil); reservoir

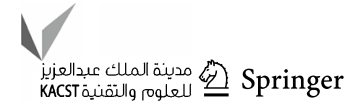


Table 7 Physical and geological terms of in situ $\mathrm{CO}_{2}$ technology applicability

\begin{tabular}{|c|c|}
\hline Reservoir & Terrigenous, carbonate \\
\hline Oil properties & $\begin{array}{l}\text { Wide range of density- }-0.75 \div 0.940 \mathrm{~g} / \mathrm{cm}^{3} \text {; and viscos- } \\
\text { ity—up to } 1000 \mathrm{cP}\end{array}$ \\
\hline Thermobaric limitation & Temperature $(\mathrm{T})>40^{\circ} \mathrm{C}$, reservoir pressure-no limitation \\
\hline Mineralization and formation water type & $\begin{array}{l}\text { Technology is effective in wide range water mineralization } \\
\text { and formation water types }\end{array}$ \\
\hline
\end{tabular}

characteristic (porosity and permeability); formation heterogeneity; reservoir correlation; minerals components.

The selection of well group acceptable for reservoir treatment is carried out by results of the dynamic analysis of oil field development, determination of reservoir drainability factor, injectivity test, estimation of hydrodynamic correlation, etc.

The field operation was performed through several cycles of injection of gas-forming and gas-releasing chemical compositions.

The following groups of wells were considered as the subjects of the test:

- The first group-injection well \#1 with 14 responding production wells;

- The second group-injection well \#2 and 12 responding production wells.

Comparative analysis of proposed groups of the wells on the subject of conformity to the requirements of the pilot treatment displayed the porosity and permeability of the reservoir. The key oil-saturated injection interval is represented by sandstones, with the wide range of permeability: from low-permeable reservoirs $-19.7 \mathrm{mD}$ to high-permeable reservoirs-4997.0 $\mathrm{mD}$; the porosity of the reservoir is $28.0-29.0 \%$ on average, and the temperature gradient is $3{ }^{\circ} \mathrm{C} / 100 \mathrm{~m}$. The production interval is characterized by interbedded intervals of water and oil saturation. The oil saturation of the reservoir is $54 \%$ on average, which can be considered as an acceptable saturation according to the requirements.

Similarity to the previous case, heavy oils are in abundant proportion in reservoir fluids, with in situ viscosity within $57.0 \div 338.0 \mathrm{MPa}$ s. Viscosity of oil under surface conditions varies from 983.0 to $4565.0 \mathrm{MPa}$ s. Formation waters are highly mineralized, of chlorocalcium and sodium type and mineralization in the range of 4481-7154 mg/l. The effects on the viscosity and production are similar to the previously mentioned example, with the positive outcome on the production wells (Table 8).

The treatment operation scheme (sequential injection of portions of gas-releasing and gas-forming compositions into the formation) is presented in Fig. 12.
Table 8 Oil properties of Penglai oil field

\begin{tabular}{ll}
\hline Density & $0.915-0.991 \mathrm{~g} / \mathrm{cm}^{3}$, average $0.961 \mathrm{~g} / \mathrm{cm}^{3}$ \\
Viscosity & $29-2471 \mathrm{mPa} . \mathrm{s}$, mainly $500 \mathrm{mPa} . \mathrm{s}$ \\
Acid number & $2-10 \mathrm{mg} \mathrm{KOH} / \mathrm{cm}^{3}$ \\
Sulfur & $0.35-0.49 \%$ \\
Asphaltenes & $0.11-3.54 \%$ \\
Paraffins & $0.46-8.8 \%$ \\
Condensation point & -28 to $4.4^{\circ} \mathrm{C}$ \\
\hline
\end{tabular}

As it was done for the previous example, the water cut and production rate were under continuous monitoring after the treatment. The performance of the responding production wells indicates a positive respond to the treatment, characterized by the surge in average daily oil rate and a decrease in water cut for most of the surrounding wells in the testing area. Preliminary results of the reservoir stimulation confirmed the increase in the total incremental oil production after treatment operation. Dynamics of the average daily oil rate and water cut for the surrounding wells of the nine-point field development system are presented in Figs. 13, 14, 15.

The $\mathrm{CO}_{2}$-EOR operations for heterogeneous reservoirs should be designed with the consideration of $\mathrm{CO}_{2}$ distribution and utilization rate, as wells as gradual oil production, with relevant understanding of the lithological and stereographical complexity, fracture gradient, and in situ fracture system.

\section{Conclusions}

Based on conducted laboratory research and field implementation, the following conclusions can be made:

1. Several physical and hydrodynamic phenomena of in situ $\mathrm{CO}_{2}$ generation in highly permeable zones of a porous medium have been achieved as a part of complex study, which involved laboratory tests on the field-scale industrial technology applications, determination of optimal concentrations of foaming reagents and inhibiting additives in gas-releasing solutions. The main hydrodynamical advantages of in situ $\mathrm{CO}_{2}$ generation are additional 


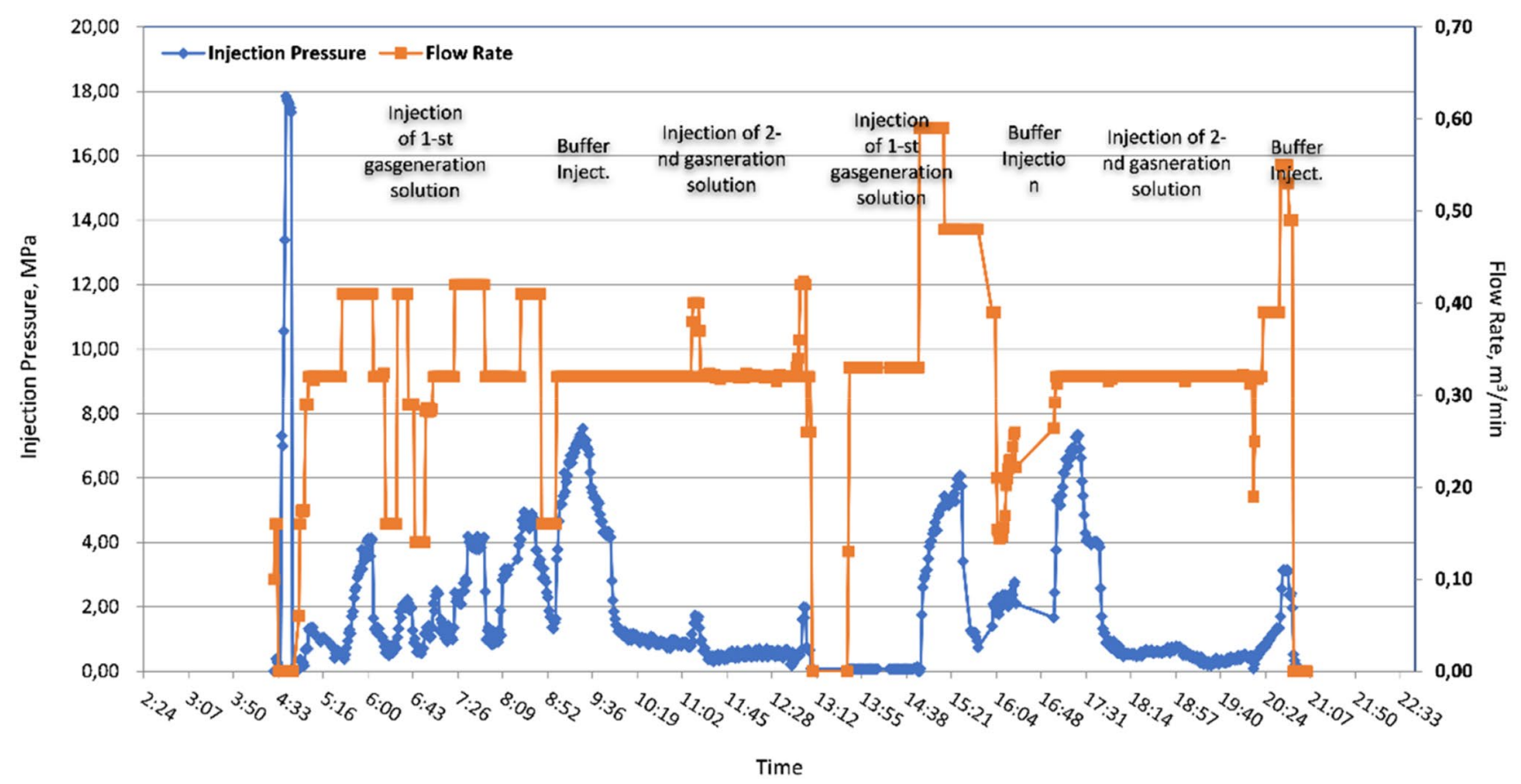

Fig. 12 Injection pressure and flow rate performance during the operation of in situ $\mathrm{CO}_{2}$-slug generation-sequential injection of portions of gas-releasing and gas-forming compositions into the formation

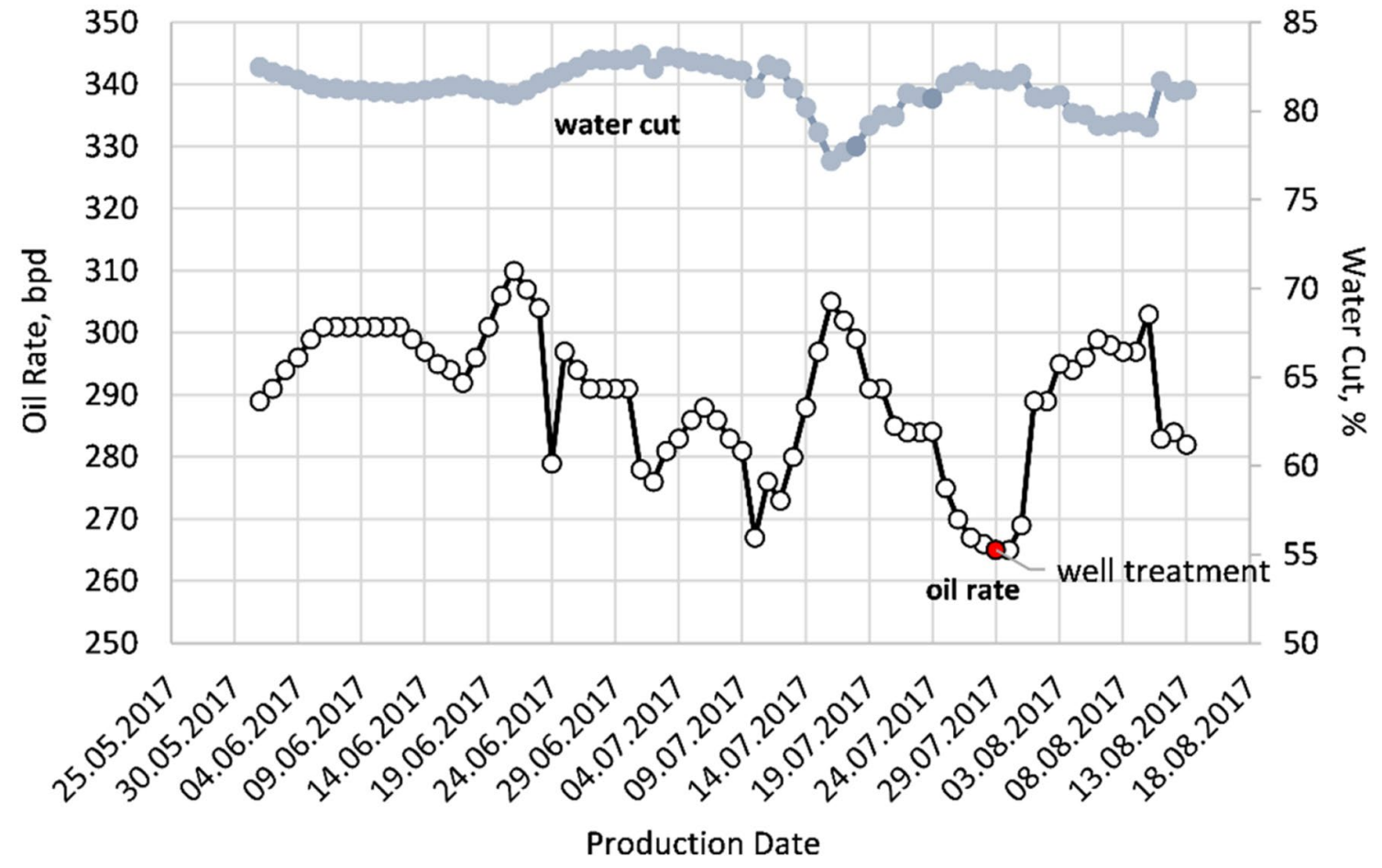

Fig. 13 Oil rate and water cut performance of \#1 responding well before and after of in situ $\mathrm{CO}_{2}$ treatment 


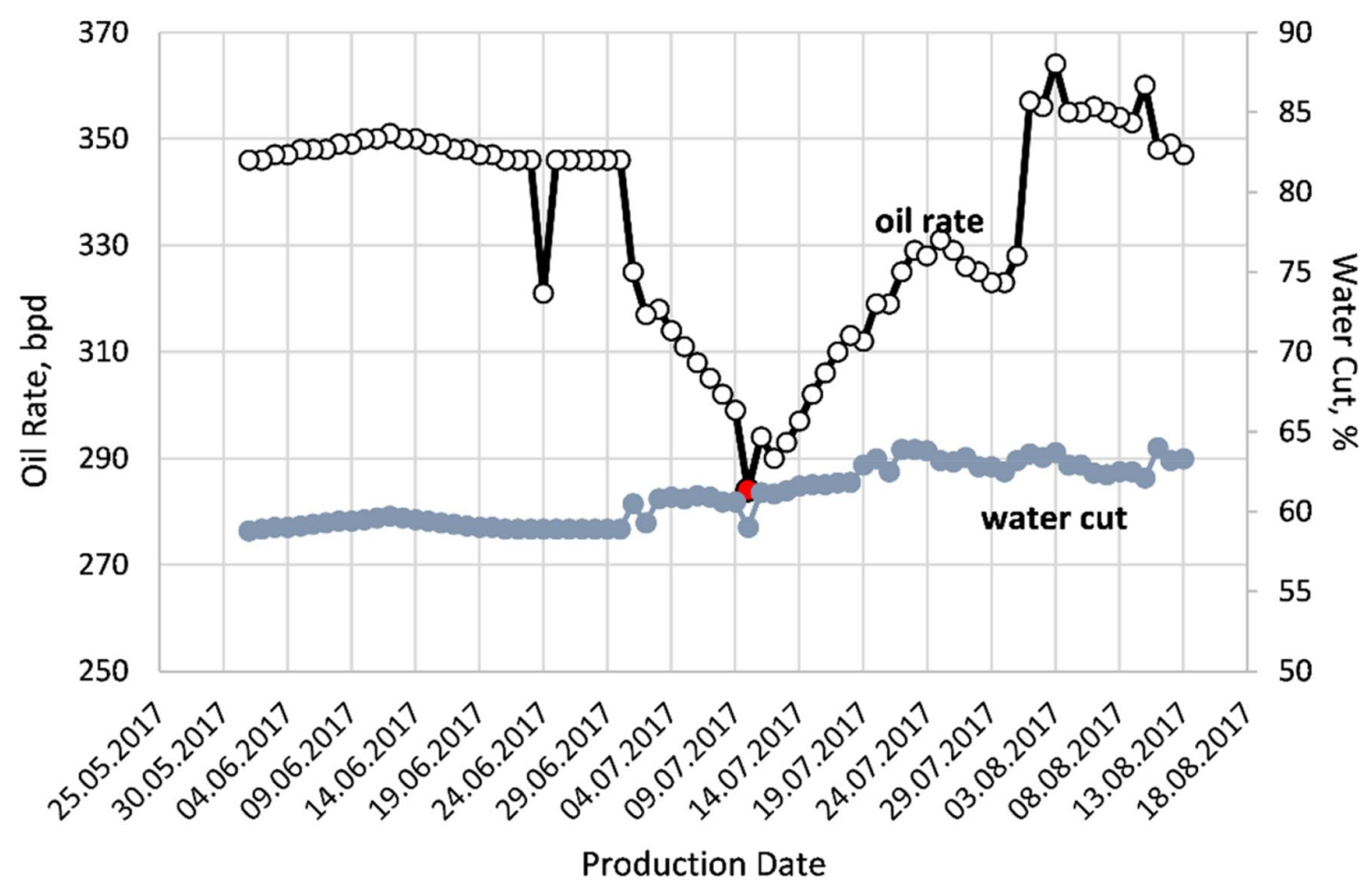

Fig. 14 Oil rate and water cut performance of $\# 2$ responding well before and after of in situ $\mathrm{CO}_{2}$ treatment

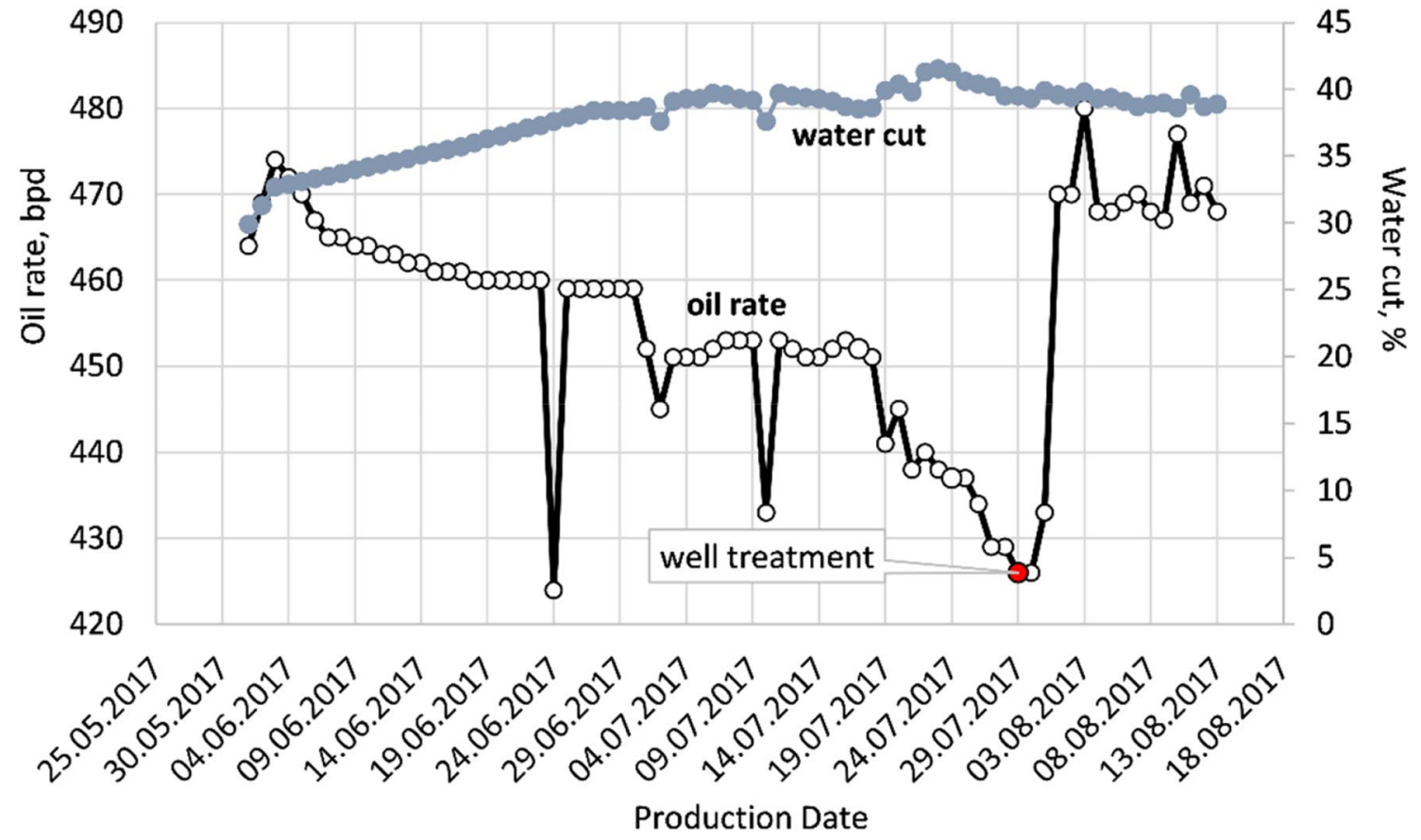

Fig. 15 Oil rate and water cut performance of \#3 responding well before and after in situ $\mathrm{CO}_{2}$ treatment 
resistance to the flow of injected water by stable foam barrier in highly permeable reservoir zones; dissolution of the in situ generated carbon dioxide, as a result of the volume effect, which widens the displacement area and provides an increase in the oil recovery factor.

2. The gas-releasing aqueous solutions are formed from the reservoir water, which are used in the process in a rapid rate of gas release into the third phase at the initial moments of the reaction. In addition, the absence of a diffusion factor leads to the best result in the distribution of water and oil saturations in the displacement zone. Intensive gas release at the initial stage of the reaction slows down the speed of the frontal saturation spike, while the rate of reservoir flooding is reduced in comparison with fresh water as a consequence.

3. Laboratory tests of the core samples with varying permeability and porosity, correlated with field properties, showed that the incremental recovery ranged between 30 and $35 \%$ oil original in place under sequential injection of portions of gas-releasing and gas-forming compositions into the porous medium.

4. At the same time, new in situ $\mathrm{CO}_{2}$ slug generation has a number of advantages that makes it stand out from conventional gas flooding technologies:

- Treatment operations in complex areas, both offshore and onshore oil and gas fields with complicated climatic conditions;

- No additional communications and power supply for $\mathrm{CO}_{2}$ injection;

- Technological advantage, defined by the absence of requirements for $\mathrm{CO}_{2}$ source and pipeline infrastructure;

- Profitability of the technology, defined by the in situ conditions for $\mathrm{CO}_{2}$ generation and formation of a gas-liquid slug.

5. Field operation results confirmed about $37,740 \mathrm{bbl}$ of incremental oil production after reservoir stimulation with in situ $\mathrm{CO}_{2}$ generation (taking into account the decrease in production for three production wells). Theoretical and laboratory studies, as well as the results of industrial implementation of a new method of residual oil recovery, using a $\mathrm{CO}_{2}$-slug confirm technology and economic profitability of the proposed solution. Technology can be considered as an effective way to increase oil recovery by actively stimulating the reservoir with in situ $\mathrm{CO}_{2}$ generation.

Funding This research was funded by SOCAR Science Foundation (Azerbaijan), grant № 28LR and China National Offshore Oil Corporation (CNOOC).

\section{Compliance with ethical standards}

Conflict of interest On behalf of all the co-authors, the corresponding author states that there is no conflict of interest.

Open Access This article is licensed under a Creative Commons Attribution 4.0 International License, which permits use, sharing, adaptation, distribution and reproduction in any medium or format, as long as you give appropriate credit to the original author(s) and the source, provide a link to the Creative Commons licence, and indicate if changes were made. The images or other third party material in this article are included in the article's Creative Commons licence, unless indicated otherwise in a credit line to the material. If material is not included in the article's Creative Commons licence and your intended use is not permitted by statutory regulation or exceeds the permitted use, you will need to obtain permission directly from the copyright holder. To view a copy of this licence, visit http://creativecommons.org/licenses/by/4.0/.

\section{References}

Al Yousef ZA, Almobarky MA, Schechter DS (2020) Surfactant and a mixture of surfactant and nanoparticles to stabilize $\mathrm{CO}_{2}$ /brine foam, control gas mobility, and enhance oil recovery. J Pet Explorat Product Technol. https://doi.org/10.1007/ s13202-019-0695-9

Al-Saedi H, Flori R, Al-Jaberi S (2019) Eliminate the role of clay in sandstone: EOR low salinity water flooding. J Petrol Explor Prod Technol 9:1475-1483. https://doi.org/10.1007/s13202-018-0548-y

Assef Y, Pereira Almao P (2019) Evaluation of cyclic gas injection in enhanced recovery from unconventional light oil reservoirs: effect of gas type and fracture spacing. Energies 12:1370. https://doi.org/ $10.3390 /$ en 12071370

Bakhtiyarov S.I., Shakhverdiev A.Kh., Panakhov G.M., Abbasov E.M. (2006) Oil Recovery by In-Situ Gas Generation: Volume and Pressure Measurements//ASME Joint U.S.-European Fluids Engineering Summer Meeting, Miami, FL, July 17-20, Paper \# FEDSM2006-983596.

Bila A, Torsæter O (2020) Enhancing oil recovery with hydrophilic polymer-coated silica nanoparticles. Energies 13:5720. https://doi. org/10.3390/en 13215720

Bromhal GS, Ferer M (1994) Pore-level modeling of carbon dioxide sequestration in oil fields: a study of viscous and buoyancy forces. Phys Rev E 49:4114

Chen Z, Liu J, Elsworth D, Connell LD, Pan Z (2010) Impact of $\mathrm{CO}_{2}$ injection and differential deformation on $\mathrm{CO}_{2}$ injectivity under in-situ stress conditions. Int J Coal Geol 81:97-108

Choubineh A, Helalizadeh A, Wood DA (2019) The impacts of gas impurities on the minimum miscibility pressure of injected $\mathrm{CO}_{2}$-rich gas-Crude oil systems and enhanced oil recovery potential. Pet Sci 16:117-126

Dake L.P. (1998) Fundamentals of reservoir engineering Shell International Petroleum Maatschappij B. V., The Hague, The Netherlands.

Eide LI, Batum M, Dixon T, Elamin Z, Graue A, Hagen S, Hovorka S, Nazarian B, Nøkleby PH, Olsen GI, Ringrose P, Vieira RAM (1945) Enabling large-scale carbon capture, utilisation, and storage (CCUS) using offshore carbon dioxide (CO2) infrastructure developments: a teview. Energies 2019:12. https://doi.org/10. 3390/en12101945

Farajzadeh R, Kahrobaei S, Eftekhari AA et al (2021) Chemical enhanced oil recovery and the dilemma of more and cleaner energy. Sci Rep 11:829. https://doi.org/10.1038/ s41598-020-80369-Z 
Farzaneh, S.A., Seyyedsar, S.M. \& Sohrabi, M. (2016) Enhanced heavy oil recovery by liquid $\mathrm{CO} 2$ injection under different injection strategies. SPE Annual technical conference and exhibition. Dubai, UAE: Society of Petroleum Engineers.

Frenkel Ya.I. (1975) Kineticheskaya teoriya zhidkostej. L.: Nauka,. (in Russian).

Huang ETS, Holm LW (1988) Effect of WAG injection and rock wettability on oil recovery during $\mathrm{CO}_{2}$ flooding. SPE Reservoir Eng 3(1):119-129

Höök M, Tang Xu, Xiongqi P, Aleklett K (2010) Development journey and outlook of Chinese giant oilfields//Petrol. Explor Develop 37(2):237-249

Hou P, Ju Y, Gao F et al (2016) Simulation and visualization of the displacement between $\mathrm{CO} 2$ and formation fluids at pore-scale levels and its application to the recovery of shale gas. Int J Coal Sci Technol 3:351. https://doi.org/10.1007/s40789-016-0155-9

Hu G, Li P, Yi L, Zhao Z, Tian X, Liang X (2020) Simulation of immiscible water-alternating-CO2 flooding in the Liuhua oilfield offshore Guangdong. China Energies 13:2130. https://doi.org/10. 3390/en13092130

Hussain M, Amao AO, Al-Ramadan K, Negara A, Saleh TA (2020) Non-destructive techniques for linking methodology of geochemical and mechanical properties of rock samples. J Pet Sci Eng 195:107804. https://doi.org/10.1016/j.petrol.2020.107804

Ibrahim MA, Saleh TA (2020) Partially aminated acrylic acid grafted activated carbon as inexpensive shale hydration inhibitor. Carbohyd Res 49:107960. https://doi.org/10.1016/j.carres.2020.107960

IEA: Commentary: Whatever happened to enhanced oil recovery? by Christophe McGlade, WEO energy analyst; Glenn Sondak, WEO energy analyst; and Mei Han, intern. 28 November 2018.

Jia B, Tsau J-S, Barati R (2019) Measurement of $\mathrm{CO}_{2}$ diffusion coefficient in the oil-saturated porous media. J Pet Sci Eng 181:106189

Kim C, Lee J (2017) Experimental study on the variation of relative permeability due to clay minerals in low salinity water-flooding. J Pet Sci Eng 151:292-304. https://doi.org/10.1016/j.petrol.2017. 01.014

Kristanto D, Hermawan YD, Hariyadi Y et al (2020) Integrated simulation system of $\mathrm{CO} 2$ gas injection application for enhanced oil recovery in the oil field. J Petrol Explor Prod Technol 10:39173923. https://doi.org/10.1007/s13202-020-00955-9

Lake LW, Johns RT, Rossen WR, Pope GA (2014) Fundamentals of Enhanced Oil Recovery. Society of Petroleum Engineers, Richardson, pp 496

Liu J, Sun L, Li Z, Wu X (1975) Experimental study on reducing $\mathrm{CO}_{2}$-Oil minimum miscibility pressure with hydrocarbon agents. Energies 2019:12. https://doi.org/10.3390/en12101975

Mandrik I.E., Panahov G.M., Shahverdiev A.H. (2010) Nauchno-metodicheskie i tekhnologicheskie osnovy optimizacii processa povysheniya nefteotdachi plastov // Moskva, «Neftyanoe hozyajstvo» Publishing. 228 p. (in Russian).

Muggeridge A, Cockin A, Webb K, Frampton H, Collins I, Moulds T, Salino P (2006) Recovery rates, enhanced oil recovery and technological limits. Philos Trans Ser A Math Phys Eng Sci 372(2006) 20120320. https://doi.org/10.1098/rsta.2012.0320

Panakhov G.M., Abbasov E.M. (2004) Experimental simulation of gas-fluid effect in heterogeneous porous medium//Transactions of AMEA, issue Mathematics and Mechanics series of physicaltechnical and mathematical sciences of Institute of Mathematics and Mechanics, XXIV, 245-252

Panakhov G.M., Omrani A.-N. (2008) Quasi-periodic in-situ foaming in processes of selective insulation of high-permeable channels of the porous medium//ANAS Transactions (Issue Mathematics and Mechanics series of Physical-Technical and Mathematical Sciences), Baku XXVIII, \#1. - pp.183 - 188.
Panakhov GM, Abbasov EM, Bakhtiyarov SI, Shakhverdiev AKh (2006) Kinetics of gas generation in water solutions//transactions of AMEA, mathematics and mechanics issue, series of physicaltechnical and mathematical sciences of institute of mathematics and mechanics. XXIV, Baku

Rodosta T, Bromhal G, Damiani DUS (2017) DOE/NETL carbon storage program: advancing science and technology to support commercial deployment. Energy Procedia 114:5933-5947

Tawfik A. Saleh, Mukaila A. Ibrahim Advances in functionalized Nanoparticles based drilling inhibitors for oil production, Energy Reports, Volume 5, 2019, Pp. 1293-1304, ISSN 2352-4847, https://doi.org/10.1016/j.egyr.2019.06.002.

Mofrad SK, Dehaghani AHS (2020) An experimental investigation into enhancing oil recovery using smart water combined with anionic and cationic surfactants in carbonate reservoir. Energy Rep 6:543-549. https://doi.org/10.1016/j.egyr.2020.02.034

Shakhverdiev A.Kh., Panahov G.M. (2000) Rheochemical technologies for stimulation of oil production Istvan Lakatos (ed): Novelities in enhanced oil and gas recovery-Akademiai Kiado, budapest, progress in mining and oil Chemistry 2: 151-158.

Shakhverdiev A.H., Panahov G.M., Abbasov E.M. (2004) Gazozhidkostnaya otorochka dlya vozdejstviya na neftyanuyu zalezh.-Trudy VNIIneft im. akad. A.P. Krylova (in Russian).

Shakhverdiev A.H., Bahtiyarov S.I., Abbasov E.M., Abdul Nasir Omrani (2008) Kvaziperiodicheskoye penoobrazovaniye v processah selektivnoy izolyacii vysokopronicaemyh kanalov poristoj sredy/«Trudy Mezhdunarodnoy nauchno-prakticheskoy konferencii «Hazarneftgazyatag-2008», Baku, pp. 155-159 (in Russian).

Shakhverdiev A.H., Panahov G.M., Abbasov E.M., Huimin Zeng, Yigang Liu, Shunyao Luo Innovacionnaya tekhnologiya izvlecheniya ostatochnyh zapasov uglevodorodov vnutriplastovoj generaciey dioksida ugleroda//Neftyanoe Hozyaystvo, №6.—2010-s. 44-48 (in Russian).

James G. Speight, Chapter 13-Upgrading by Gasification, Editor(s): James G. Speight, Heavy oil recovery and upgrading, Gulf Professional Publishing. Doi: https://doi.org/10.1016/B978-0-12813025-4.00013-1.

Tian J, Hao F, Zhou X, Zou H, Lan L (2014) Charging of the Penglai 9-1 oil field, Bohai Bay basin, China: functions of the delta on accumulating petroleum. Mar Pet Geol 57:603-618. https://doi. org/10.1016/j.marpetgeo.2014.07.007

Trivedi JJ, Babadagli T (2009) Oil recovery and sequestration potential of naturally fractured reservoirs during $\mathrm{CO}_{2}$ injection. Energy Fuels 23(8):4025-4036

Valluri MK, Zhou J, Mishra S, Mohanty K (2020) $\mathrm{CO}_{2}$ injection and enhanced oil recovery in ohio oil reservoirs-an experimental approach to process understanding. Energies 13:6215. https://doi. org/10.3390/en 13236215

Zhang J, Zhou ZW, Wang WS, Tao LB (2004) EOR field test of gaswater alternative injection in Pubei oilfield. Pet Explor Dev 31:85-87

Zhang YN, Wang TL, Han X, Wang ZM, Zhang J (2016) Corrosion of artificial rock layer covered steel electrodes in $\mathrm{a} \mathrm{CO}_{2}$ environment: the influence of permeability. Corrosion Sci 105:190-201. https:// doi.org/10.1016/j.corsci.2016.01.017

Publisher's Note Springer Nature remains neutral with regard to jurisdictional claims in published maps and institutional affiliations. 